\title{
House Price Booms, Current Account Deficits, and Low Interest Rates*
}

\author{
Andrea Ferrero \\ (andrea.ferrero@economics.ox.ac.uk) \\ University of Oxford
}

August 15, 2014

\begin{abstract}
Domestic factors, such as credit and preference shocks, can explain the negative correlation between house prices and the current account in the United States and several other countries before the recent crisis. These shocks, however, cannot account for the fall of world real interest rates observed in the data. Expansionary monetary policy shocks in the United States, coupled with exchange rate pegs to the dollar in emerging economies, are crucial to understand the evolution of the real interest rate. Yet, monetary policy factors play virtually no role for house prices and the current account.
\end{abstract}

Keywords: borrowing constraints, monetary policy, exchange rate pegs

JEL codes: E52, E58, F32, F41

*Prepared for the conference on "Housing, Stability and the Macroeconomy: International Perspectives," held at the Federal Reserve Bank of Dallas on November 14-15, 2013. Thanks to the Editors (Robert DeYoung and Anthony Murphy) and three anonymous Referees for their criticisms and suggestions, and to Edward Leamer, Jean Imbs and Frederic Boissay for their discussions. I have also benefitted from comments by seminar participants at INSEAD, the Paris School of Economics, the Midwest Macroeconomics Meetings (Nashville), the 2011 New York University Alumni Conference, the North American Econometric Society Meeting (St. Louis), the Society for Economic Dynamics (Ghent), the European Economic Association (Oslo), the Graduate Institute for Policy Studies, Rutgers University at Newark, the Federal Reserve Bank of Cleveland, the CEPR/MGI Workshop (Paris), the Central Bank of Chile, and the 2013 MAFFAP Workshop (Pavia). I am grateful to John Duca, John Muellbauer and Anthony Murphy for kindly sharing their data on loan-to-value ratios. Daniel Herbst provided excellent research assistance. 

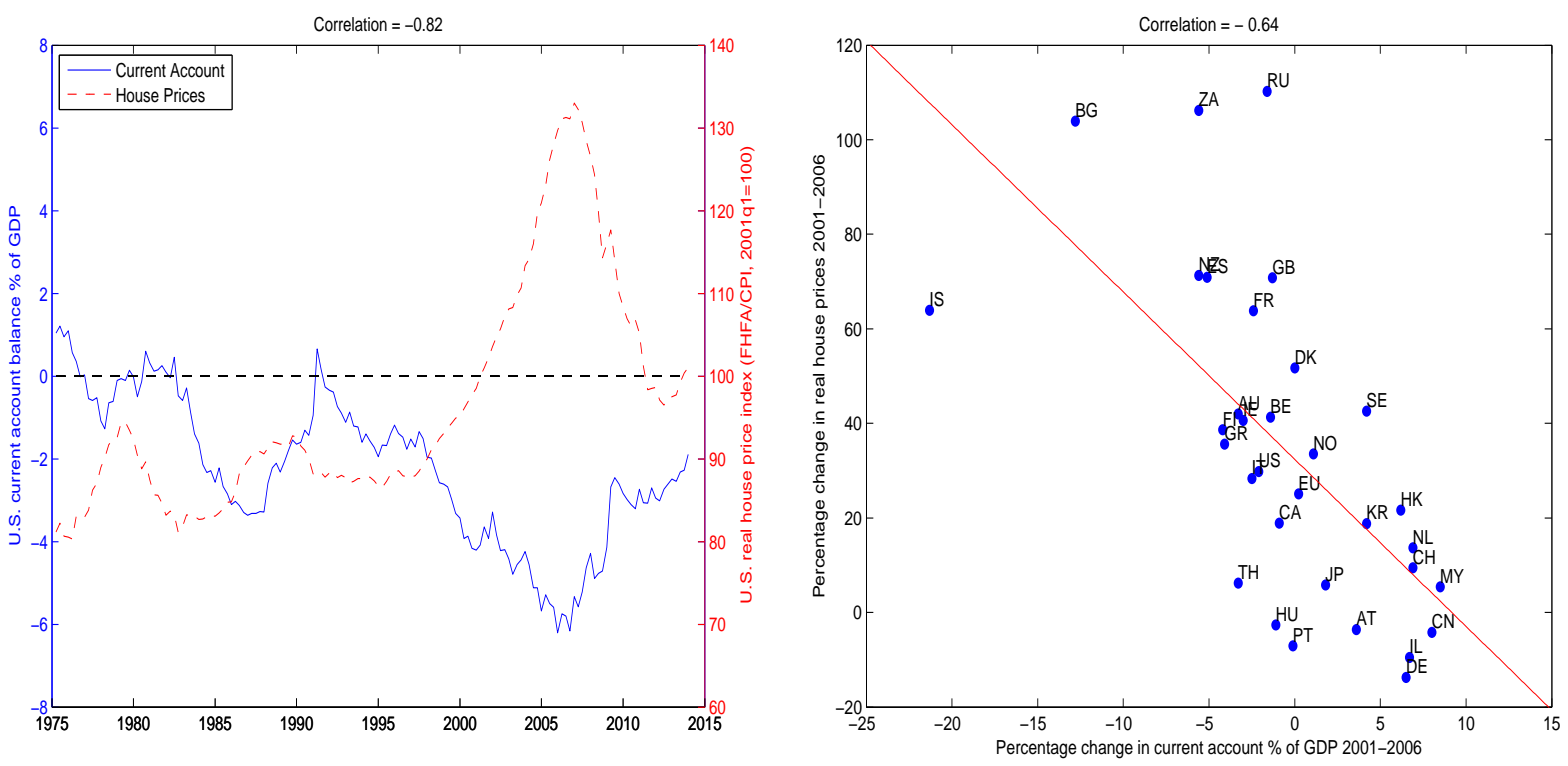

Figure 1: Left panel: U.S. current account balance \% of GDP (left axis) and FHFA existing one-family house price index deflated by headline CPI (right axis, 2001q1 $=100$ ). Source: Bureau of Economic Analysis and Federal Housing Finance Agency. Right panel: Percentage changes in current account \% of GDP and in real house prices for advanced and emerging economies between 2001 and 2006. Source: Bank of International Settlements.

\section{Introduction}

The boom-bust episode in U.S. house prices during the 2000s has been a fundamental determinant of the Great Recession. During the same period, the U.S. current account markedly deteriorated, before improving after 2006. Before the crisis, these two variables were perhaps the most discussed indicators of U.S. imbalances (Greenspan, 2005). Interestingly, the negative correlation between house prices and the current account was not just specific to the U.S. (left panel of Figure 1) but rather a robust global phenomenon, affecting advanced and emerging market economies alike (right panel of Figure 1). ${ }^{1}$

Policymakers have hinted in several occasions (e.g. Bernanke, 2010) at the strong negative correlation between house prices and the current account as a way to gauge a better understanding of the events that led to the unfolding of the recent crisis. At a first pass, a key distinction to make progress in this direction is to ascertain whether domestic or foreign factors should form the main basis for a candidate explanation of the housing cycle.

The first result in this paper is to demonstrate that domestic factors (credit and preference

${ }^{1}$ Countries that witnessed the largest house prices booms and current account deficits (such as Greece, Iceland, Ireland, Spain and the U.S.) also experienced the highest degree of financial turmoil during the crisis. Similar dynamics for capital inflows and real estate prices occurred before the Asian crisis in the late 1990s (see Obstfeld and Rogoff, 2010, and the references therein). 

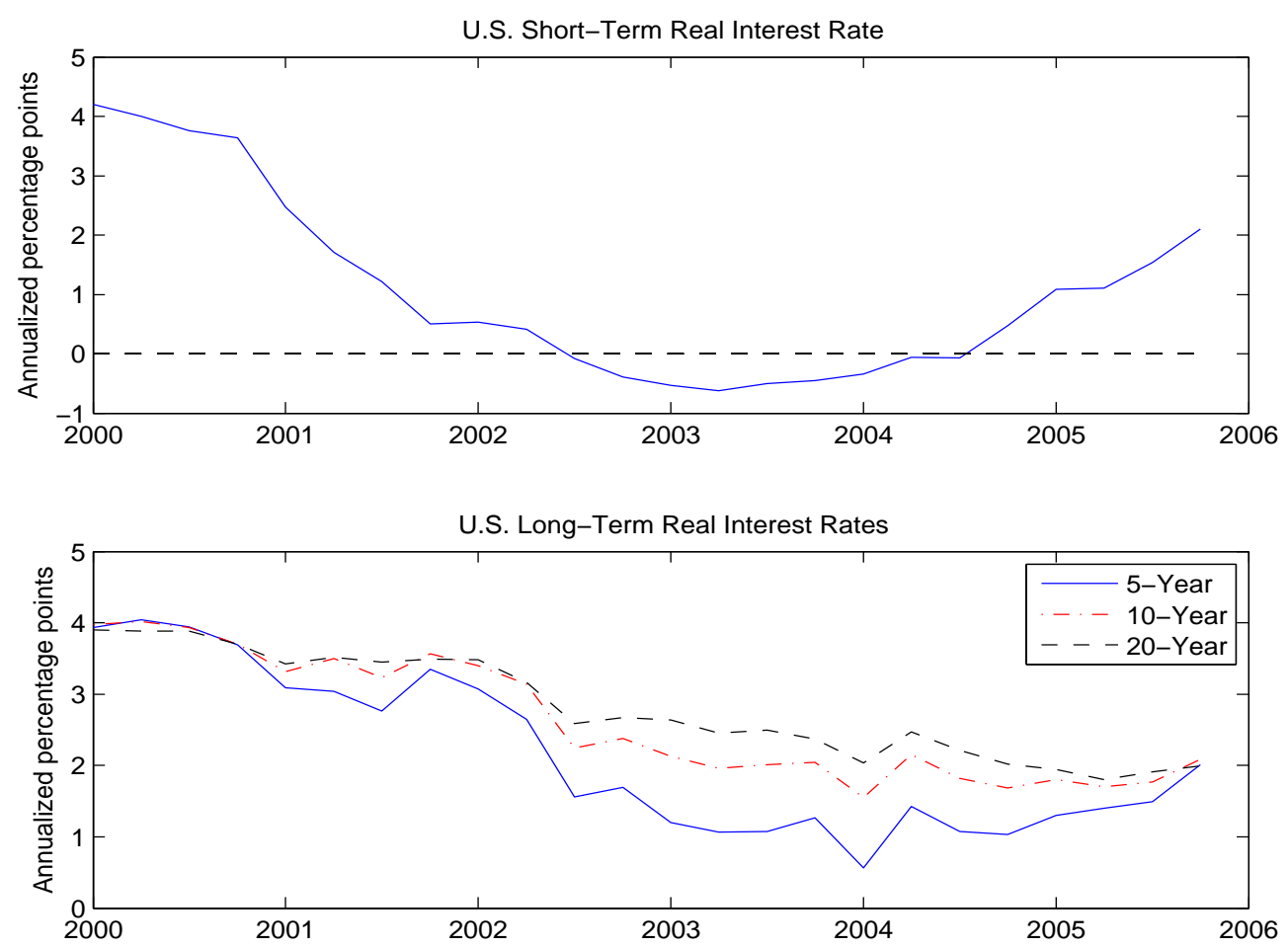

Figure 2: Top panel: U.S. short-term real interest rate (nominal 1-year T-bill yield minus expected inflation from the Survey of Professional Forecasters). Bottom panel: U.S. longterm real interest rate at different maturities (implied from Treasury Inflation-Protected Securities). Source: Board of Governors of the Federal Reserve and Federal Reserve Bank of Philadelphia.

shocks) can generate the house price boom observed in the data, as well as a non-negligible portion of the current account deterioration. This view is consistent with several pieces of both anecdotal and hard evidence on financial deregulation and innovation, as well as with the notion of a house price bubble, but raises an important issue. Domestic factors that cause an increase in house prices are akin to demand shocks, which put upward pressure on the equilibrium real interest rate. In contrast, the evidence shows that real interest rates sharply declined during the early 2000s (Figure 2).

The second contribution of the paper is to show that a combination of expansionary monetary policy in the U.S. and a regime of managed exchange rates in the rest of the world can account for low global real interest rates. Importantly, however, credit and preference shocks remain the main driver of house price and current account dynamics, with monetary factors only playing a minor role. The focus on monetary policy in the U.S. and in the rest of the world sets this paper apart from other contributions that have relied on domestic shocks to explain house price booms, current account deficits, and low interest rates (e.g. Favilukis et al., 2011; Boz and Mendoza, 2014). 
The punch line of the paper, therefore, is a dichotomy between the fundamental factors that explain house prices and the current account (credit and preference shocks), and those that explain the real interest rate (monetary policy shocks and foreign pegs).

This message does not disprove, but rather complements, what is probably the current consensus that some variation of the so-called "global savings glut" hypothesis (Bernanke, 2005) can account for the joint observation of increasing house prices and capital inflows toward the U.S. between the late 1990s and the mid 2000s. According to this view, some type of domestic financial imperfections create excess savings in emerging economies, which, in a world of free international capital markets, seek investment opportunities in more advanced countries (primarily the U.S.). ${ }^{2}$

Conversely, the results in the paper provide no support for the view that loose U.S. monetary policy was the key determinant of house price appreciation, and the current account deficit was a side consequence due to the stimulus to consumption associated with the monetary expansion (Taylor, 2008). From a qualitative perspective, expansionary monetary policy shocks do contribute to amplify the boom in house prices as well as to widen the current account deficit. However, their quantitative contribution is extremely small. The implication is that, according to the analysis in this paper, factors other than monetary policy were the key driver behind the housing boom and the deterioration of the current account. ${ }^{3}$

Finally, the results also qualify the so-called "Bretton Woods II" view of global imbalances (Dooley et al., 2008). According to this hypothesis, a key determinant of the large U.S. current account deficits in the late 1990s and early 2000s was the wide diffusion of exchange rate pegs to the dollar in emerging Asian economies and among oil producers. The analysis shows that, if domestic factors drive house price and current account dynamics, foreign exchange rate pegs provide little amplification for these variables, but do contribute to propagate low U.S. interest rates to the rest of the world.

The analysis relies on a calibrated incomplete-markets, two-country framework with tradable consumption goods and housing, whose purchases are subject to an endogenous borrowing constraint as in Kiyotaki and Moore (1997). Credit shocks are identified as the innovations of the fitted process for non-government loan-to-value (LTV) ratios for first-time buyers (Duca et al., 2011). An increase in the borrowing constraint parameter, for a given collateral value,

\footnotetext{
${ }^{2}$ The two seminal papers that model the global savings glut hypothesis are Caballero et al. (2008a) and Mendoza et al. (2009). In the former, a global savings glut arises because of a shortage of liquid assets in emerging economies, while in the latter financial markets in those regions offer fewer risk-sharing opportunities. Building on their earlier work, Caballero et al. (2008b) show that the global demand for liquidity can give rise to large U.S. current account deficits and asset price booms, especially in the housing sector due to the securitization process. See also Sá and Wieladek (2011) for an empirical contribution that supports this view.

${ }^{3}$ This conclusion is consistent with the arguments in Bernanke (2010) and the evidence in Favilukis et al. (2013) on financial innovation and credit standards, as well as with the notion of a bubble in Shiller (2007).
} 
leads households to lever up and demand more consumption of goods and housing services, hence driving up house prices and strengthening the initial effect of the credit shock. ${ }^{4}$ As the relaxation of credit constraints affects the whole economy, the rest of the world finances the increase in domestic borrowing, thus generating a current account deficit. Housing preference shocks give rise to similar equilibrium dynamics, thus also delivering a negative correlation between house prices and the current account as in Gete (2013), although the consequences for foreign indebtedness are slightly smaller. ${ }^{5}$

A combination of credit and preference shocks constitutes the baseline scenario that accounts for the full house price boom and about half of the actual deterioration of the current account between 2001 and 2006. ${ }^{6}$ This scenario, however, features a counterfactual evolution of the real interest rate, which remains roughly stable during the boom period.

Monetary policy shocks - identified as departures of the measured Federal Funds Rate (FFR) from the interest rate implied by a standard feedback (Taylor) rule in the U.S. during the period 2001-2006 - are the missing ingredient to align the model with the data. After the 2001 recession, U.S. nominal interest rates remained lower than predicted by a Taylor rule until well into 2006. With stable inflation expectations, low nominal rates translate into low real rates.

Foreign pegs project this effect onto global interest rates. As governments in emerging economies try to stimulate their exports (their main source of growth) by keeping their currencies artificially undervalued relative to fundamentals, a peg impairs a depreciation of the dollar that would trigger an earlier renormalization of interest rates. Consequently, global interest rates reach lower levels than with flexible exchange rates.

The rest of the paper proceeds as follows. Section 2 presents the model. Section 3 discusses the calibration. Section 4 introduces the baseline experiments, highlighting the implication for the real interest rate. Section 5 addresses the quantitative importance of overly-accommodative U.S. monetary policy and foreign exchange rate pegs. Finally, Section 6 concludes.

\footnotetext{
${ }^{4}$ Eggertsson and Krugman (2012) and Guerrieri and Lorenzoni (2012) argue that the reverse mechanism-a tightening of borrowing constraints relative to pre-crisis levels - can lead to a substantial drop in aggregate demand and potentially create depression-like scenarios.

${ }^{5}$ Iacoviello and Neri (2010) estimate a closed economy DSGE model with housing and find that housing preference shocks are a key driver of house prices at business cycle frequencies. In a two-country, two-type (borrowers and savers in each country) model with residential investment, Punzi (2013) shows that the impulse responses to preference shocks for housing are broadly consistent with VAR evidence.

${ }^{6}$ Midrigan and Philippon (2011) use a similar combination of credit and preference shocks in an island economy to match the distribution of house prices across U.S. counties.
} 


\section{A Two-Country Model with Borrowing Constraints}

Time is discrete and indexed by $t$. Two countries of equal size (Home and Foreign) form the world economy. In each country, a representative household consists of a continuum of measure one of workers. Within the household, all members share the consumption of a tradable composite of goods produced domestically and abroad, as well as housing services, which are assumed to be proportional to the fixed housing stock. An endogenous collateral constraint limits the maximum amount of private credit to a fraction of the expected value of housing. A representative retailer packages differentiated intermediate goods into the homogeneous final tradable good. A continuum of measure one of monopolistic competitive firms produce the intermediate goods, using labor as the only factor of production. A representative labor agency combines the differentiated labor inputs into the homogeneous aggregate. Goods and labor markets are imperfectly competitive. Prices and wages are set on a staggered basis. The law of one price holds but home bias in consumption implies that purchasing power parity is violated. International financial markets are incomplete. The only asset traded across countries is a one-period nominal risk-free bond denominated in the Home currency. All exogenous shocks considered below are specific to the Home country. The first is a preference shock for housing. The second is a change in the tightness of the borrowing constraint parameter. The third is an innovation to the monetary policy rule.

The model is deliberately simple and abstracts from a number of important factors - such as within-country borrowing and lending, heterogenous locations, and elastic housing supplywhich have certainly played a role in the housing market during the years that preceded the recent crisis. The key objective is to use the model to show that domestic factors can generate a boom in house prices, and evaluate its consequences for the current account and, most importantly, real interest rates.

This section presents the household and firms' problems from the perspective of the Home country. An asterisk denotes foreign variables when relevant. The Appendix reports the optimality conditions.

\subsection{Household Preferences and Constraints}

The representative household maximizes the expected discounted value of a utility function which depends positively on the consumption index $X_{t}$, and negatively on hours worked by each member of the representative household $L_{t}(i)$

$$
U_{t} \equiv \mathbb{E}_{t}\left\{\sum_{s=0}^{\infty} \beta^{s}\left[\frac{X_{t+s}^{1-\sigma}}{1-\sigma}-\frac{1}{1+\nu} \int_{0}^{1} L_{t+s}(i)^{1+\nu} d i\right]\right\}
$$


where $\mathbb{E}_{t}$ is the expectation operator conditional on the information set available at time $t$, $\beta \in(0,1)$ is the discount factor, $\sigma>0$ is the coefficient of relative risk aversion and $\nu>0$ is the inverse Frisch elasticity of supply of a specific labor input.

The index $X_{t}$ combines consumption of goods $C_{t}$ and housing services $H_{t}$ with constant elasticity of substitution $\epsilon>0$

$$
X_{t} \equiv\left[\omega C_{t}^{\frac{\epsilon-1}{\epsilon}}+(1-\omega) e^{\eta_{t}} H_{t}^{\frac{\epsilon-1}{\epsilon}}\right]^{\frac{\epsilon}{\epsilon-1}}
$$

where $\omega \in(0,1)$ is the share of tradable goods in total consumption and $\eta_{t}$ is a preference shock for housing that follows a first-order autoregressive process

$$
\eta_{t}=\rho_{\eta} \eta_{t-1}+\varepsilon_{\eta t}
$$

with $\rho_{\eta} \in(0,1)$ and $\varepsilon_{\eta t} \sim$ i.i.d. $\mathcal{N}\left(0, \sigma_{\eta}^{2}\right)$. As in Iacoviello and Neri (2010) and Justiniano et al. (2013), a positive preference shocks for housing takes the form of an increase in $\eta_{t}{ }^{7}$

The tradable bundle $C_{t}$ combines consumption of goods produced in the Home $\left(C_{h t}\right)$ and Foreign $\left(C_{f t}\right)$ country with constant elasticity of substitution $\gamma>0$

$$
C_{t} \equiv\left[\alpha^{\frac{1}{\gamma}} C_{h t}^{\frac{\gamma-1}{\gamma}}+(1-\alpha)^{\frac{1}{\gamma}} C_{f t}^{\frac{\gamma-1}{\gamma}}\right]^{\frac{\gamma}{\gamma-1}},
$$

where $\alpha \in[0.5,1)$ is the share of domestic tradable goods. ${ }^{8}$ Expenditure minimization implies that the consumption-based domestic price index is

$$
P_{t}=\left[\alpha P_{h t}^{1-\gamma}+(1-\alpha) P_{f t}^{1-\gamma}\right]^{\frac{1}{1-\gamma}}
$$

where $P_{j t}$ is the price of good $j=\{h, f\}$ defined in Home currency. The law of one price holds for tradable goods (i.e. $P_{j t}=\mathcal{E}_{t} P_{j t}^{*}$, where $\mathcal{E}_{t}$ is the nominal exchange rate). However, because of home bias in preferences, purchasing power parity fails (i.e. $P_{t} \neq \mathcal{E}_{t} P_{t}^{*}$ ), and the real exchange rate $\left(S_{t} \equiv \mathcal{E}_{t} P_{t}^{*} / P_{t}\right)$ is generally different from one.

The budget constraint for the representative household in nominal terms is

$$
P_{h t} C_{h t}+P_{f t} C_{f t}+\mathcal{Q}_{t} H_{t}-\mathcal{B}_{t} \leq \int_{0}^{1} W_{t}(i) L_{t}(i) d i+\mathcal{P}_{t}+\mathcal{Q}_{t} H_{t-1}+T_{t}-\left(1+i_{t-1}\right) \mathcal{B}_{t-1},
$$

${ }^{7}$ Gete (2013) considers preference shocks for housing that induce time variation in $\omega$. This alternative formulation has a direct impact on the Euler equation for consumption too, while $\eta_{t}$ in this model only affects directly the house price equation.

${ }^{8}$ Given the assumption $\alpha>0.5$, preferences for tradable goods exhibit home bias. The Foreign tradable bundle places a weight $\alpha$ on consumption of Foreign tradable goods. 
where $\mathcal{Q}_{t}$ is the price of housing, $W_{t}(i)$ is the wage for the specific labor input supplied by the $i^{\text {th }}$ household member, $\mathcal{P}_{t}$ are profits from ownership of intermediate goods producers, $T_{t}$ are lump-sum transfers and $i_{t}$ is the net nominal interest rate on an internationally-traded one-period risk-free debt instrument $\mathcal{B}_{t}$, denominated in the Home currency.

Within each country, household members perfectly pool their idiosyncratic consumption risk due to staggered price and wage setting. The representative household can smooth consumption intertemporally by borrowing and lending in international financial markets, subject to a collateral constraint that depends on the expected value of housing

$$
\left(1+i_{t}\right) \mathcal{B}_{t} \leq \Theta_{t} \mathbb{E}_{t}\left(\mathcal{Q}_{t+1} H_{t}\right)
$$

where the borrowing constraint parameter $\Theta_{t} \in(0,1)$ follows a first-order autoregressive process in log-deviations from steady state

$$
\theta_{t} \equiv \ln \left(\Theta_{t} / \Theta\right)=\rho_{\theta} \theta_{t-1}+\varepsilon_{\theta t}
$$

with $\rho_{\theta} \in(0,1)$ and $\varepsilon_{\theta t} \sim$ i.i.d. $\mathcal{N}\left(0, \sigma_{\theta}^{2}\right)$. The idea behind this type of borrowing constraint is that the Foreign household can only recover a fraction $\Theta_{t}$ of the collateral in case of default, possibly due to various costs associated with the bankruptcy process. ${ }^{9}$

In the model, all borrowing occurs from abroad. In practice, of course, most households borrow from domestic financial institutions to finance their consumption and housing purchases, and part of these funds come from other domestic households. Yet, during the early 2000 s, the increase in funds originating from abroad crucially contributed to the credit boom. The working hypothesis in this paper is that these capital flows are the result of increased demand in the U.S. induced by financial deregulation/innovation and preference for housing. ${ }^{10}$

\footnotetext{
${ }^{9}$ See, for instance, Kiyotaki and Moore (1997) and Iacoviello (2005). An alternative formulation (e.g. Kocherlakota, 2000) would feature the current value of housing on the right-hand side of the constraint and would represent a more direct mapping between the borrowing constraint parameter in the model and LTV ratios in practice. Section 4 discusses this mapping for calibration purposes. Quantitatively, the results are not sensitive to the two different specifications.

${ }^{10}$ As mentioned in the introduction, the global savings glut hypothesis suggests instead a foreign origin for the capital flows toward the United States. The recent work by Acharya and Schnabl (2010) and Bruno and Shin (2014) qualifies the savings glut narrative, adding a role for global banks. In a quantitative equilibrium model, Justiniano et al. (2014b) find that the combined effect of the savings and banking glut accounts for between one-fourth and one-third of the increase in house prices and household debt that preceded the crisis.
} 


\subsection{Labor Agencies and Wage Setting}

Perfectly competitive labor agencies hire differentiated labor inputs from household members and supply intermediate goods producers with the composite

$$
L_{t}=\left[\int_{0}^{1} L_{t}(i)^{\frac{\phi_{w}-1}{\phi_{w}}} d i\right]^{\frac{\phi_{w}}{\phi_{w}-1}}
$$

where $\phi_{w}>1$ is the elasticity of substitution among differentiated labor inputs. Profit maximization for labor agencies gives the demand for the $i^{\text {th }}$ labor input

$$
L_{t}(i)=\left[\frac{W_{t}(i)}{W_{t}}\right]^{-\phi_{w}} L_{t}
$$

where $W_{t}$ is the aggregate wage index implied by the zero profit condition for labor agencies

$$
W_{t}=\left[\int_{0}^{1} W_{t}(i)^{1-\phi_{w}} d i\right]^{\frac{1}{1-\phi_{w}}} .
$$

Household members are monopolistic supplier of their labor inputs and set wages on a staggered basis. In each period, independently of previous adjustments, the probability of not being able to reset the wage is $\zeta_{w}$. A household member who is able to reset the wage at time $t$ solves

$$
\max _{\tilde{W}_{t}(i)} \mathbb{E}_{t}\left\{\sum_{s=0}^{\infty}\left(\beta \zeta_{w}\right)^{s}\left[\lambda_{t+s} \tilde{W}_{t}(i) L_{t+s}(i)-\frac{1}{1+\nu} L_{t+s}(i)^{1+\nu}\right]\right\}
$$

subject to (7) conditional on no further wage changes, where $\lambda_{t}$ is the marginal utility of consumption at time $t$. The Appendix reports the details on the first order condition and derives the associated wage Phillips curve.

\subsection{Firms and Production}

Competitive retailers pack intermediate goods according to a constant returns technology with elasticity of substitution $\phi_{p}>1$

$$
Y_{h t} \equiv\left[\int_{0}^{1} Y_{t}(h)^{\frac{\phi_{p}-1}{\phi_{p}}} d h\right]^{\frac{\phi_{p}}{\phi_{p}-1}}
$$


Profit maximization gives the demand for the $h^{\text {th }}$ good

$$
Y_{t}(h)=\left[\frac{P_{t}(h)}{P_{h t}}\right]^{-\phi_{p}} Y_{h t},
$$

where $P_{h t}$ is the aggregate price index for goods produced in the Home country implied by the zero profit condition for final goods producers

$$
P_{h t}=\left[\int_{0}^{1} P_{t}(h)^{1-\phi_{p}} d h\right]^{\frac{1}{1-\phi_{p}}} .
$$

All intermediate goods producing firms (indexed by $h$ ) have access to the same constant return technology, which uses the labor aggregate $L_{t}$ as the only factor of production

$$
Y_{t}(h)=A L_{t}(h)
$$

where $A$ is a constant productivity factor. Intermediate goods producers set prices in domestic currency on a staggered basis, where $\zeta_{p}$ is the probability of not being able to adjust the price in the future, independently of previous adjustments. A firm that can reset its price at time $t$ solves

$$
\max _{\tilde{P}_{t}(h)} \mathbb{E}_{t}\left\{\sum_{s=0}^{\infty}\left(\beta \zeta_{p}\right)^{s} \lambda_{t+s}\left[\tilde{P}_{t}(h) Y_{t, t+s}(h)-W_{t+s} L_{t+s}(h)\right]\right\}
$$

subject to the technology constraint (10) and to the demand for their product (9) conditional on no further price changes in the future, which the firm takes as given. ${ }^{11}$ The Appendix reports the details on the first order condition and derives the associated price Phillips curve.

Finally, the stock of housing (land) is assumed to be fixed

$$
H_{t}=H
$$

This assumption gives the model the best chance to match the increase of house prices in response to domestic shocks. In practice, the housing boom was also accompanied by a large increase in residential investment. ${ }^{12}$ However, interpreting housing as land fits well the evidence in Davis and Heathcote (2007), who find that land prices, rather than the price of structures,

\footnotetext{
${ }^{11}$ The representative household in each country owns the domestic firms. Therefore, the marginal utility of consumption, i.e. the Lagrange multiplier on the budget constraint, is the appropriate measure to convert the value of future profits in units of current consumption.

${ }^{12}$ In an estimated closed economy DSGE model with borrowers and savers, Iacoviello and Neri (2010) find that slow technological progress in the housing sector explains the long run upward trend in U.S. house prices, while housing technology shocks account for about $25 \%$ of the variance of house prices at business cycle frequencies.
} 
explain the bulk of both trend growth and cyclical house price fluctuations between 1975 and 2006 .

\subsection{Monetary Policy}

In models with housing, the price index $P_{t}$ is typically not a sufficient statistic for inflation. The price index that central banks target in practice includes a significant weight on "ownerequivalent rent," that is, the rent that would be paid if a currently-owned property were to be rented. The idea is to include the cost of shelter in the index that measures the overall living costs.

Although the model abstracts from a rental market, owner-equivalent rent $\left(O E R_{t}\right)$ can be defined as the price that an individual would pay to the owner to use the house for one period. In a competitive market, this price should equal the marginal rate of substitution between housing and consumption net of depreciation (Diaz and Luengo-Prado, 2008). Given the assumption of a fixed housing stock in this model, the resulting measure, excluding preference shocks, is

$$
O E R_{t} \equiv \frac{1-\omega}{\omega}\left(\frac{H}{C_{t}}\right)^{-\frac{1}{\epsilon}}
$$

The price index relevant for monetary policy decision is then assumed to be a weighted average of goods and owner-equivalent rent

$$
P_{X t} \equiv P_{t}^{\omega_{X}} O E R_{t}^{1-\omega_{X}}
$$

where $\omega_{X} \in(0,1)$ is the relative weight on goods prices.

The central bank sets the short-term nominal interest rate in response to deviations of inflation and output from their targets

$$
\left(1+i_{t}\right)=\left(1+i_{t-1}\right)^{\rho_{i}}\left[(1+i)\left(\frac{\Pi_{X t}}{\tilde{\Pi}_{t}}\right)^{\varphi_{\pi}}\left(\frac{Y_{h t}}{\tilde{Y}_{h t}}\right)^{\varphi_{y}}\right]^{1-\rho_{i}} e^{\varepsilon_{i t}},
$$

where $\rho_{i} \in(0,1)$ is the degree of interest rate smoothing, $\Pi_{X t} \equiv P_{X t} / P_{X t-1}, \varphi_{\pi}>1$ and $\varphi_{y}>0$ govern the intensity of the interest rate response to inflation and output, respectively, $\tilde{\Pi}_{t}$ and $\tilde{Y}_{h t}$ are the targets for inflation and output, respectively, and $\varepsilon_{i t} \sim$ i.i.d. $\mathcal{N}\left(0, \sigma_{i}^{2}\right)$ is a monetary policy shock. 


\subsection{Equilibrium and Steady State}

An imperfectly competitive equilibrium for the world economy is a sequence of prices and quantities such that:

1. The representative household in each country maximizes utility subject to the budget constraint and the collateral constraint, taking prices as given. The household also sets wages on a staggered basis on behalf of its members to minimize the disutility of labor, taking demand for their specific labor input as given.

2. Intermediate goods producing firms set prices on a staggered basis to maximize the present discounted value of profits, taking the demand for their variety as given. Final goods producing firms minimize costs, taking prices as given.

3. The housing and labor markets clear in each country. Goods and financial markets clear internationally.

The Appendix reports the full list of equilibrium conditions, the steady state, and the log-linear approximation of the model used for the quantitative experiments discussed below.

In two-country open economy models, the steady state is typically a symmetric equilibrium in which the net foreign asset position is zero. In the context of this model, zero foreign debt implies that the borrowing constraint in neither country can be binding in steady state, otherwise the borrowing constraint would pin down net foreign debt. The unattractive feature of a symmetric steady state for current purposes is that, up to a linear approximation, borrowing constraints become irrelevant for house prices dynamics. A log-linear approximation of the equation for real house prices $\left(Q_{t} \equiv \mathcal{Q}_{t} / P_{t}\right)$ yields

$$
\begin{array}{r}
q_{t}=(1-\beta-\Xi \Theta)\left(\frac{1}{\epsilon} c_{t}+\eta_{t}\right)+\beta\left[\left(\frac{1}{\epsilon}-\sigma\right)\left(\mathbb{E}_{t} x_{t+1}-x_{t}\right)-\frac{1}{\epsilon}\left(\mathbb{E}_{t} c_{t+1}-c_{t}\right)\right]+\beta \mathbb{E}_{t} q_{t+1} \\
+\Xi \Theta\left[\xi_{t}+\theta_{t}+\mathbb{E}_{t}\left(\pi_{t+1}+q_{t+1}\right)\right]
\end{array}
$$

where lower case variables denote log-deviations from steady state and $\Xi$ is the steady state value of the Lagrange multiplier on the borrowing constraint. The first line of the righthand side of (13) is a standard user-cost equation for housing (durable goods), under the assumption of fixed supply. Real house prices are equal to the the current marginal utility of housing services in units of marginal utility of consumption plus the discounted expected value of future house prices. The second line measures the contribution of the shadow value of the borrowing constraint to current house prices. If the borrowing constraint were not to be binding in steady state, the multiplier would be equal to zero $(\Xi=0)$. Therefore, up to a first order approximation, changes in the borrowing constraint parameter $\theta_{t}$ would have no 
effects on real house prices.

The strategy to get around this issue adopted in this paper is to assume that the borrowing constraint always binds in the Home country because its representative household is relatively more impatient than the Foreign country's one $\left(\beta<\beta^{*}\right) .{ }^{13}$ This assumption is quite common in closed economy models with borrowers and savers, starting with Kiyotaki and Moore (1997). In open economy, the reason why it may be reasonable to think of the the Home country (the U.S.) as being always a net borrower in international financial markets is related to the desire of investors in the rest of the world (and in particular in emerging markets) to hold dollardenominated financial assets. Most importantly, differential discounting allows for shocks to the borrowing constraint to play a role in affecting house prices dynamics, at the cost of giving rise to an asymmetric steady state. This asymmetry, however, is small and limited to the steady state quantities. An appropriate normalization of the relative level of productivity and of the housing stock makes relative prices equal across countries. ${ }^{14}$

\section{Calibration}

The Foreign discount factor pins down the steady state real return on the internationally traded asset. A target of $4 \%$ for the annualized real return implies $\beta^{*}=0.99$. The Home country is a net borrower in international financial markets because of a lower discount factor $\left(\beta<\beta^{*}\right)$. The next section discusses the exact value of this parameter in details.

The coefficient of risk aversion $\sigma$ and the inverse Frisch elasticity of labor supply $\nu$ are both set equal to 2 , within the range of common practice in macroeconomics (see, for instance, Hall, 2010). Also standard are the values for the elasticity of substitution among goods and labor varieties $\left(\phi_{p}=\phi_{w}=7.67\right)$, which are calibrated to match steady state a $15 \%$ markup in both the goods and labor market (Woodford, 2003). The price and wage stickiness parameters $\left(\zeta_{p}=\zeta_{w}=0.75\right)$ are chosen to match an average duration of price and wage contracts of four quarters (Nakamura and Steinsson, 2008).

The parameters of the goods consumption basket are fairly common in the international macroeconomics literature (see, for instance, Obstfeld and Rogoff, 2007). The domestic share of tradable consumption $\alpha$, which governs the degree of home bias, is set to 0.7 . The elasticity

\footnotetext{
${ }^{13}$ The Appendix reports the evolution of the Lagrange multiplier on the borrowing constraint across the different simulations and shows that, in the main experiments, the multiplier is always positive. Additionally, in practice, the available evidence suggests quite clearly that before the crisis the marginal borrower was always taking out the maximum possible loan, in spite of the progressive relaxation of borrowing constraints.

${ }^{14}$ Interestingly, the presence of a binding borrowing constraint also solves the problem of indeterminacy of the net foreign asset position typical of open economy models with incomplete international financial markets (SchmittGrohé and Uribe, 2003). The borrowing constraint at equality pins down the steady state level of net foreign assets as a function of house prices and the real interest rate.
} 
of substitution between Home and Foreign tradable goods $\gamma$ equals 2 .

The intratemporal elasticity of substitution between goods consumption and housing services $\epsilon$ is set equal to one. A Cobb-Douglas specification of the aggregator $X_{t}$ is consistent with the micro evidence from the Decennial Census of Housing in Davis and Ortalo-Magné (2011), indicating that expenditure shares on housing are constant over time and across U.S. metropolitan areas. Conditional on the elasticity of substitution, the share of goods in the consumption aggregator $\omega$ is chosen to match a non-housing share of total expenditure of about 83\%, which is in line with the average for the U.S. from 1929 to 2001 (Piazzesi et al., 2007). ${ }^{15}$ The relative stock of housing is adjusted so that in steady state the level of house prices in the two countries is the same.

For simplicity, the steady state value of the terms of trade (and hence of the real exchange rate and the relative prices of Home and Foreign tradable goods) are normalized to one by appropriately picking the steady state productivity ratio $A / A^{*}$.

The targets and parameters of the monetary policy rule take fairly conventional values (e.g. Galí and Gertler, 2007). The inflation target is normalized to zero and the target for output is its steady state value. The interest rate smoothing parameter $\rho_{i}$ is set equal to 0.7. As in Taylor (1993), the response to inflation $\psi_{\pi}$ equals 1.5 while the response to output $\psi_{y}$ equals 0.5. Finally, the weight $\omega_{X}$ on goods inflation in the price index $P_{X t}$ targeted by the central bank is set equal to 0.7 , which implies a $30 \%$ weight on owner-equivalent rent ("Shelter" minus "Lodging away from home" and "Tenants' and household insurance") as in the U.S. Consumer Price Index (McCarthy and Peach, 2010).

The calibration of the stochastic process of the shocks (borrowing constraint parameter, preference and monetary policy) is discussed in details in the next sections that present the main quantitative experiments.

\section{Domestic Shocks and House Price Booms}

This section considers two types of domestic shocks that can generate house price boom-bust episodes of the magnitude observed in the U.S. and in other advanced economies in the 2000s. The first shock is a relaxation of the collateral constraint parameter $\Theta_{t}$. The second shock is an exogenous shift in the relative preference for housing $\eta_{t}$. 


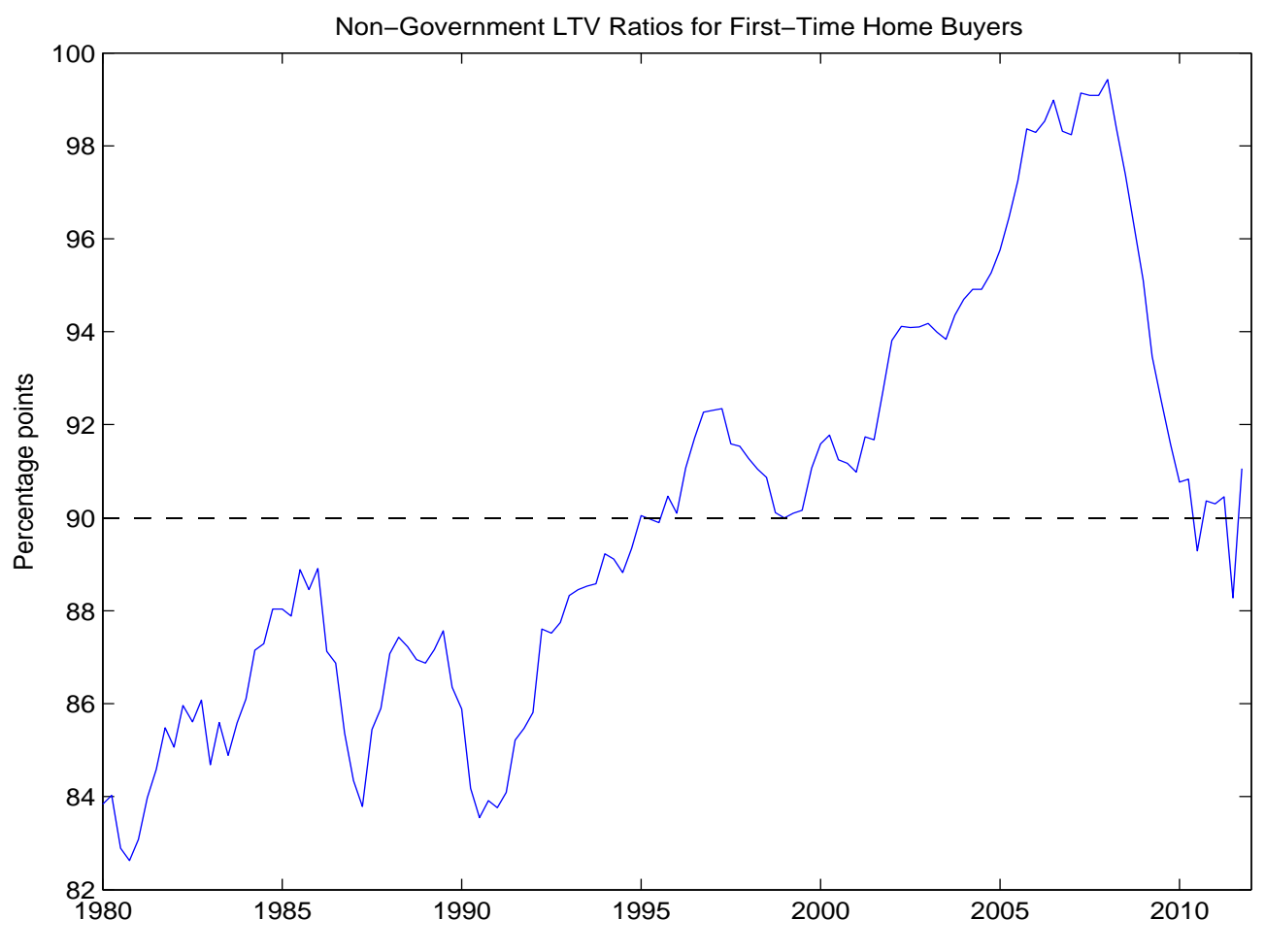

Figure 3: LTVs for first-time homebuyers (source: Duca et al., 2011).

\subsection{Relaxation of Borrowing Constraints}

A relaxation of the borrowing constraint parameter $\Theta_{t}$ is meant to capture the effect of financial deregulation, and the ensuing process of innovation, that started during the early 1980s on private borrowing (Campbell and Hercowitz, 2005). This process shifted into higher gear in the late 1990s and early 2000s, leading to an increase in household debt from 58\% to $78 \%$ of GDP between the beginning of 2001 and the end of 2005 (Brown et al., 2013). The housing sector (mortgage debt and home equity loans) accounts for almost the whole increase (Justiniano et al., 2013).

One of the most notable dimensions of the process of financial deregulation/innovation is the increase in loan-to-value (LTV) ratios for homebuyers. Duca et al. (2011) calculate a five-quarter moving average of the median LTV for first-time homebuyers from the American Housing Survey between 1979 and 2011, excluding government loans. As Figure 3 shows, this LTV series fluctuates around $85 \%$ until the early 1990s, then displays a first increase toward $90 \%$ by the end of that decade, only to accelerate further and peak at almost $100 \%$ between

\footnotetext{
${ }^{15}$ In order to match the same target, the value of $\omega^{*}$ is slightly higher for the Foreign country, where the borrowing constraint is slack.
} 
2005 and 2006, before reverting back to $90 \%$ by 2011. Importantly, Duca et al. (2011) show that this LTV series moves in locksteps with the share of outstanding mortgages securitized into private-label mortgage-backed securities - an indication that the years of the housing boom witnessed a disproportionate share of non-prime borrowing. ${ }^{16}$

Other data sources confirm this pattern for LTVs. Glaeser et al. (2013) find that the median combined LTV ratio on all housing purchases rose from $80 \%$ in 2004 to $90 \%$ in 2006 . Moreover, extreme leverage, in the form of $100 \%$ LTV, was available and used by at least $10 \%$ of borrowers. This fraction became at least $25 \%$ in 2006. Abraham et al. (2008) document the increase in subprime lending as percentage of new mortgage origination after 2001 and note that Alt-A and subprime mortgages typically had much higher cumulative LTVs.

The U.S. was not alone in this process. Most countries that were subsequently hit the worst by the financial crisis featured similar trends. In Iceland, LTV ratios increased from $65 \%$ to $90 \%$ in 2003 before going back to 80\% in 2006 (European Mortgage Federation, 2008). The country experienced a $60 \%$ increase in real house prices between 2001 and 2006, together with one of the largest deteriorations of the current account (more than $20 \%$ as a percentage of GDP) ever observed in Western economies. A similar episode took place in Ireland, where LTVs for first-time homebuyers rose from $72 \%$ in 2000 to $92 \%$ in 2006 (McCarthy and McQuinn, 2013). Irish house prices grew by $40 \%$ while the current account worsened by $3 \%$. On the surface, the case of Spain is different. The common explanation for the Spanish housing boom relies on factors related to housing demand, such as strong income growth, foreign demand for vacation homes, and immigration flows (Cortina, 2009). Spanish authorities explicitly limited LTV ratios for securitized mortgages. However, inflated appraisals may have contributed to circumvent these limits, so that higher leverage may have amplified demand shocks (Duca et al., 2010). The unfolding of the crisis confirmed that Spanish banks extended mortgages to many subprime-like households.

Historical episodes of financial deregulation/innovation, followed by house price booms and external imbalances, are also not new. Mortgage market liberalizations occurred in the U.K. at the beginning of the 1980s, when overall down-payment requirements dropped from $25 \%$ to $15 \%$ (Ortalo-Magné and Rady, 2004), and from 15\% to 5\% for first-time homebuyers (Kuvshinov, 2010). During that decade, real house prices increased by about $70 \%$ and the current account moved from a $2 \%$ surplus to a $5 \%$ deficit. Outside Europe, Williams (2009) finds evidence that financial liberalizations in the 1980s and 1990s account for about half of the trend increase in real house prices in Australia over the period 1972-2006.

While the rationale and the origins of the deregulation and innovation process, and of the

\footnotetext{
${ }^{16}$ Government Sponsored Enterprises (Fannie Mae or Freddie Mac) would typically securitize prime conforming mortgages.
} 
ensuing credit boom, are certainly interesting per-se and well-worth investigating, the analysis below starts from the presumption that a relaxation of borrowing constraints occurred and studies the consequences on asset prices and macroeconomic quantities. ${ }^{17}$ In the model, the relaxation of the borrowing constraint parameter is then a domestic demand shock in the sense that lower values of $\Theta$ allow Home households to borrow more and hence increase their consumption of both goods and housing services.

Qualitatively, the intuition for why a relaxation of borrowing constraints generates a house price boom is simple. Suppose for a moment the Home country is a small open economy which takes the world gross interest rate $R$ as given. Further, abstract from nominal rigidities and assume the Home country receives a fixed endowment of a single consumption good $Y$. Finally, simplify preferences to be log-separable in consumption and housing. In a steady state with binding borrowing constraint, the real value of the housing stock in this economy is

$$
Q H=\frac{(1-\omega) C}{\omega(1-\beta-\Xi \Theta)},
$$

where $\Xi=(1-\beta R) / R>0$ is the steady state Lagrange multiplier on the borrowing constraint. The borrowing constraint at equality requires that debt is equal to a fraction of the discounted real value of the housing stock

$$
B=\frac{\Theta Q H}{R}
$$

Holding consumption constant, a permanent increase in the borrowing constraint parameter $\Theta$ drives up the real value of the housing stock (equation 14). At the same time, the higher borrowing constraint parameter directly increases borrowing from abroad - an effect endogenously strengthened by the house price boom (equation 15). In the new steady state, the drop in consumption, necessary to pay back the higher foreign debt by running trade surpluses, partly mitigates the gains in house prices $(C=Y-(R-1) B)$. Along the transition, however, consumption is temporarily higher because the increase in debt allows agents to spend more resources both on housing and goods consumption. The mitigating effect of intertemporal solvency on foreign liabilities kicks in only at a later stage. ${ }^{18}$

\footnotetext{
${ }^{17}$ Rajan (2010) argues that easy credit in the U.S. was the consequence of the political response to increasing income inequality. Mian et al. (2013) show that, in the early 2000s, the mortgage industry started aggressively lobbying representatives from districts with a large fraction of subprime borrowers. Favara and Imbs (2010) trace instead the increase in supply of mortgage credit back to the deregulation of cross-state ownership of banks that started with the Interstate Banking and Branching Efficiency Act of 1994 (see Justiniano et al., 2014a, for a formalization of this hypothesis). Dynan et al. (2006) discuss other factors that may have contributed to explain the sharp rise in private credit.

${ }^{18}$ Simulations of a permanent increase of the collateral constraint in this simplified version of the model suggest that the long-term negative effect on consumption is small relative to the early boom, so that the direct impact of
} 


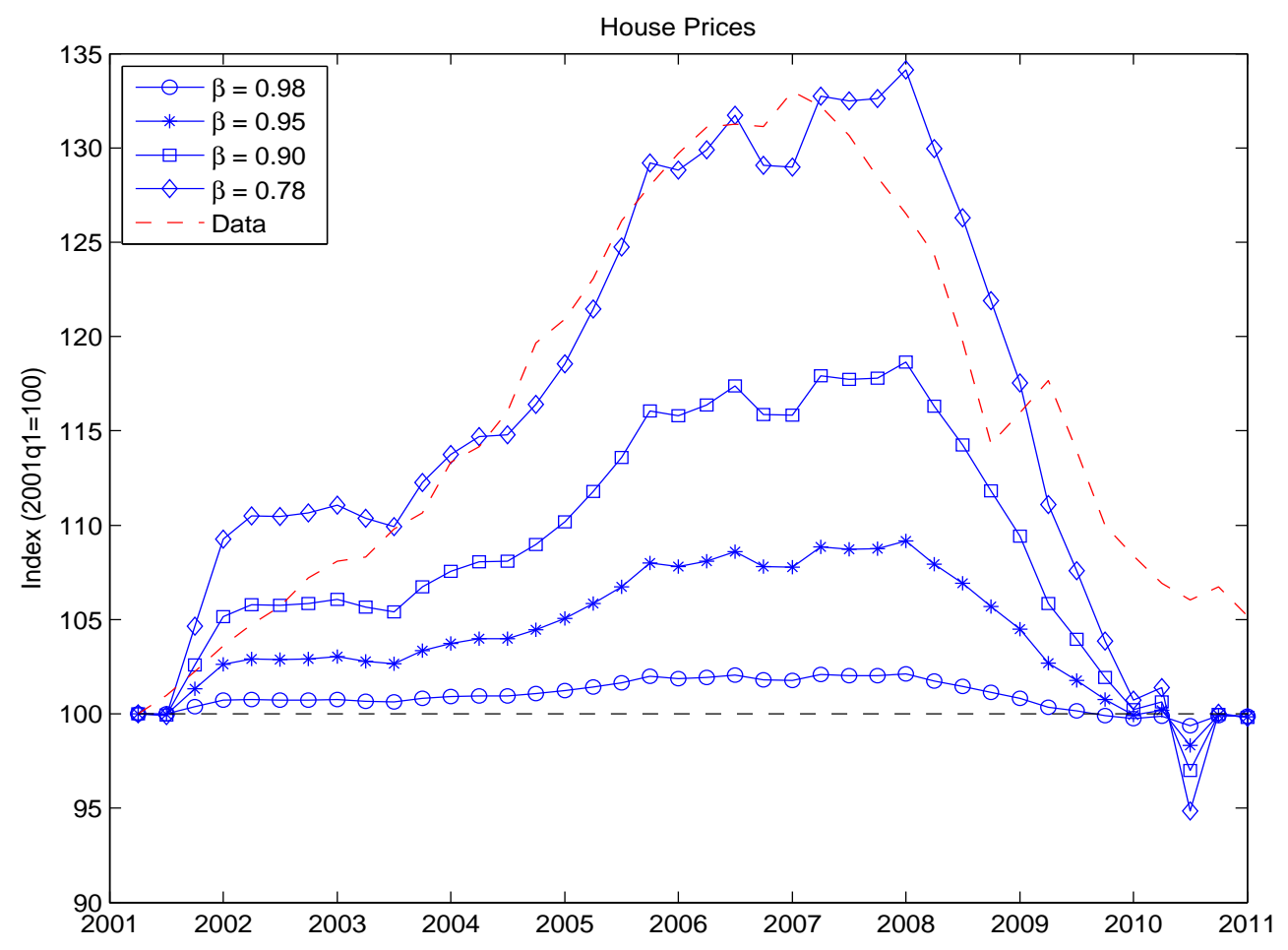

Figure 4: Real house prices in the model (for different values of $\beta$ ) in response to LTV shocks (marked continuous blue line), and in the data (dashed red line).

The same intuition goes through in a two-country world with nominal rigidities. The quantitative relevance of the relaxation of borrowing constraints for the dynamics of house prices and the other macroeconomic variables crucially depends on the calibration of the stochastic process for $\theta_{t}$. Narrowly interpreted, the parameter $\Theta$ represents the loan-to-value (LTV) ratio. The experiments below use the data from Duca et al. (2011) displayed in Figure 3 to calibrate the stochastic process for the LTV parameter. The steady state borrowing constraint parameter matches the sample average LTV $(\Theta=0.90)$. The autoregressive coefficient equals the least-squares estimate of a regression of the LTV series on its first lag $\left(\rho_{\theta}=0.98\right)$. Finally, the residuals from the same regression represent the innovations of the process $\left(\varepsilon_{\theta t}\right) .{ }^{19}$

The other key parameter for the quantitative importance of LTV shocks in accounting for the boom in house prices is the value of the borrowing country discount factor $\beta$. Figure 4 plots the evolution of house prices in the model in response to the LTV shocks identified from the data between 2001 and 2011 for four different values of $\beta$ against the data. In the

financial deregulation/innovation on house prices dominates the long-run adjustment due to debt accumulation. See also Boz and Mendoza (2014), who study the amplification effect of learning following borrowing constraint shocks in a small open economy environment.

${ }^{19}$ The coefficient estimate is significant at the $1 \%$ confidence level (t-statistic $=62.22$ ). The $R^{2}$ is 0.97 . 
intermediate cases, credit shocks explain between one-third and two-third of the house price boom-bust cycle.

These numbers may actually underestimate the importance of financial deregulation and innovation for house prices. Indeed, the mapping between borrowing constraints in the model and LTV ratios in the data is rather restrictive. First, in the context of the model, the variable $\mathcal{B}$ does not strictly represent a mortgage contract but any form of collateralized borrowing that households can obtain against the value of housing. Mian and Sufi (2011) document that home equity loans by existing homeowners are responsible for a significant fraction of the increase in U.S. household leverage and the increase in consumption between 2002 and $2006 .{ }^{20}$ Second, the model has a stationary population of households who continuously refinance their loans. In practice, however, high LTVs allowed many new borrowers who previously could not afford a loan to become homeowners (Geanakoplos, 2010a,b). ${ }^{21}$ Third, while the relaxation of borrowing constraints in the model is the only dimension of financial deregulation/innovation, the actual process affected several other aspects of credit availability, for example reduced transaction costs (Favilukis et al., 2011). The combination of these three considerations would imply a larger extent of the deregulation/innovation process. Additionally, Boz and Mendoza (2014) argue that imperfect information and learning may lead borrowers to interpret deregulated credit markets as a new permanent regime - an effect that would correspond to an increase in the perceived persistence of the LTV process in the model. For a given value of the individual discount factor, LTV shocks would then account for a bigger fraction of the observed house price dynamics.

\subsection{Preference Shocks: An Equivalence Result}

While the evidence on the relaxation of credit constraints in collateralized borrowing is quite pervasive, their importance in accounting for the house price boom is not uncontroversial. For example, Glaeser et al. (2013), in spite of the evidence of higher LTV ratios and extreme leverage in their sample, conclude that the magnitude of the observed LTV changes is not large enough to explain a significant fraction of the increase in house prices in a standard user cost model. ${ }^{22}$ Their conclusion is consistent with the results in Iacoviello and Neri (2010) and

\footnotetext{
${ }^{20}$ See also Greenspan and Kennedy (2008) on home equity extraction and Duca et al. (2012) on collateral consumption effects.

${ }^{21} \mathrm{By}$ the end of 2005 , the marginal borrowers were mostly in the subprime segment and were often able to obtain a mortgage with zero down-payments. Haughwout et al. (2011) document that the median LTV ratios on securitized non-prime mortgages from First American CoreLogic Loan Performance data increased from 95\% in 2004 to $99 \%$ in 2006 and was equal to $100 \%$ for the $75^{\text {th }}$ percentile throughout this period.

${ }^{22}$ The results in Glaeser et al. (2013) may underestimate the importance of higher LTVs, as their data (DataQuick) refer mostly to conventional mortgages and mix first-time buyers with existing owners.
} 


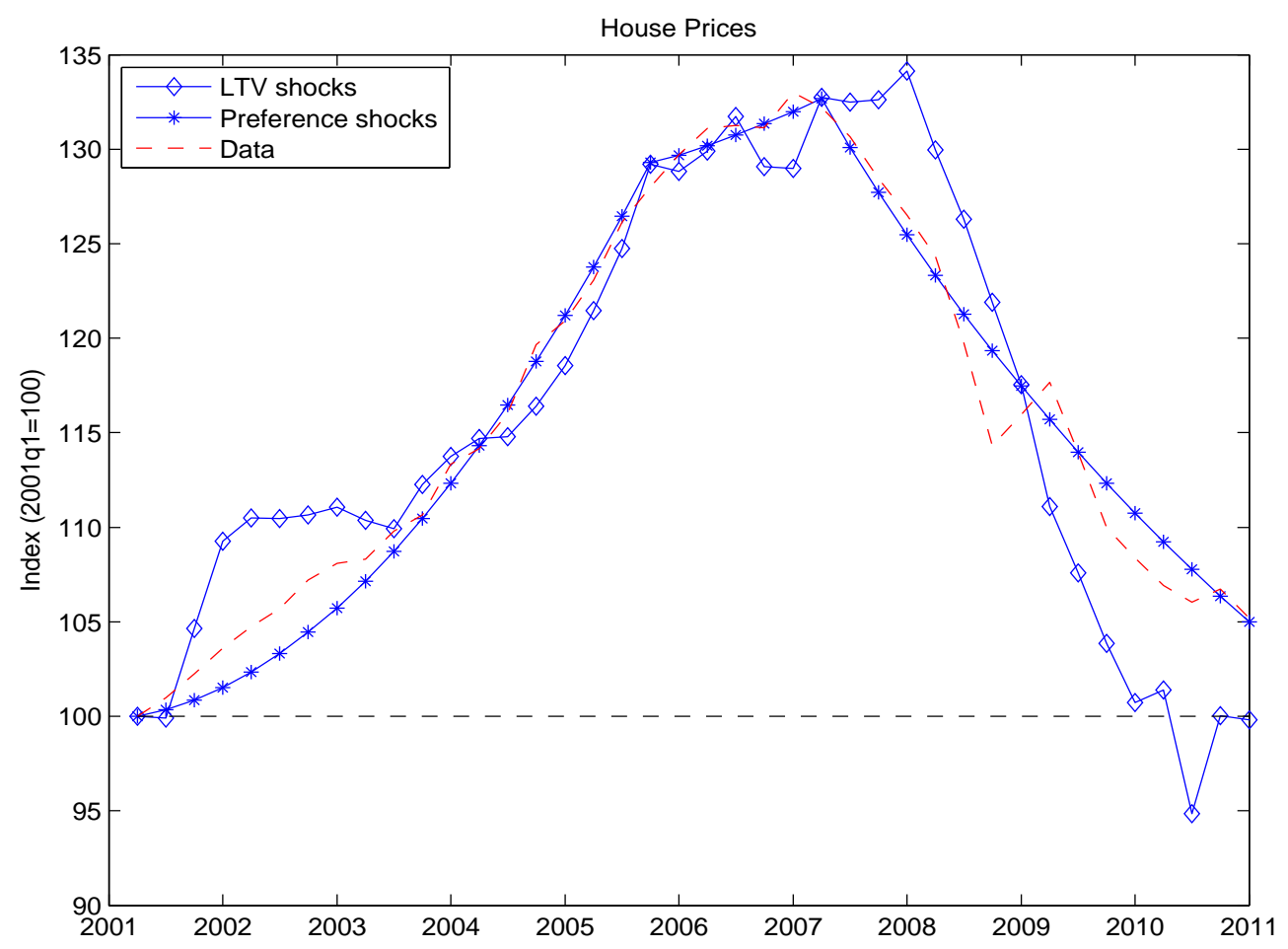

Figure 5: Real house prices in the model in response to LTV shocks (continuous blue line with diamonds) and preference shocks (continuous blue line with stars), and in the data (dashed red line).

Justiniano et al. (2013), who attribute the bulk of the increase in house prices to preference shocks for housing - possibly a stand-in for a "bubble" component independent of fundamentals. While both these papers work in a closed economy environment, Gete (2013) shows that preference shocks can explain house price booms also in an open economy setting, leading to a negative correlation with the current account.

Motivated by these considerations, which emphasize a different kind of domestic shocks, Figure 5 compares a simulation driven by preference shocks for housing (blue line with stars) with the relaxation of borrowing constraints experiment in the previous section in the case $\beta=0.78$ (blue line with diamonds) and the data (dashed red line). The preference shocks simulation is constructed feeding the model with a sequence of unexpected positive innovations to $\eta_{t}$ until 2007 and negative thereafter, engineered to match the evolution of house prices over the sample period (the persistence of the preference shock $\rho_{\eta}$ is set to 0.99).

Preference shocks and LTV shocks can give rise to very similar house price dynamics. The log-linearized house price equation (13) shows why this equivalence result should not be too surprising. The direct impact of a relaxation of borrowing constraint (an increase in $\theta_{t}$ ) is just 
a scaled version of the direct impact of a preference shock for housing (an increase in $\eta_{t}$ )

$$
q_{t}=(1-\beta-\Xi \Theta) \eta_{t}+\Xi \Theta \theta_{t}+e v_{t}
$$

where $e v_{t}$ stands for "endogenous variables." General equilibrium effects (i.e. the response of $e v_{t}$ ), and the response of other variables in the model, may lead to favor either of the two shocks as the principal domestic candidate to explain house price dynamics.

The next section focuses on the consequences of the house price boom for the current account and the real interest rate. Because the financial deregulation/innovation experiment requires very low values of the individual discount factor to match the full increase in house prices, the rest of the paper considers an even split between LTV and preference shocks in generating the house price boom-bust cycle (baseline scenario). The value of the Home country discount factor such that LTV shocks account for half of the overall increase in house prices is $\beta=0.93$ - a number more in line with the existing literature (e.g. Iacoviello, 2005).

\subsection{The Current Account and the Real Interest Rate}

The relaxation of credit constraints, combined with preference shocks for housing, drives the house price boom (top panel of Figure 6).

The two shocks induce households to increase collateralized borrowing. The main difference is that preference shocks do not affect debt directly, as credit shocks do. Consequently, the evolution of foreign indebtedness is not as extreme as in the data. Obviously, factors other than the boom-bust in the housing sector also played a non-negligible role for the current account in practice. Similarly, the evolution of debt partly represents the redistribution of resources between domestic savers and borrowers. ${ }^{23}$ Yet, the model tracks the evolution of the current account quite closely over the sample (middle panel of Figure 6). Quantitatively, the current account worsens from 4 to almost $5 \%$ over the boom period-about $50 \%$ of the actual deterioration. Similarly, as house prices slow down, the current account improves, with a comparable quantitative performance. The correlation between house prices and the current account is negative over the entire simulated sample, and is particularly strong during the boom period (-0.69), as noted in Bernanke (2010).

In spite of the success of the model in replicating the dynamics of house prices and the negative correlation with the current account, simulations based on domestic shocks predict a counterfactual path for the real interest rate (bottom panel of Figure 6). In the data, the U.S. short-term real interest rate fell substantially in the first half of the 2000s, even turning

${ }^{23}$ The Appendix reports plots of debt scaled by different aggregates (initial debt, GDP, house price value). Overall, the model captures the dynamics of these ratios fairly well. 

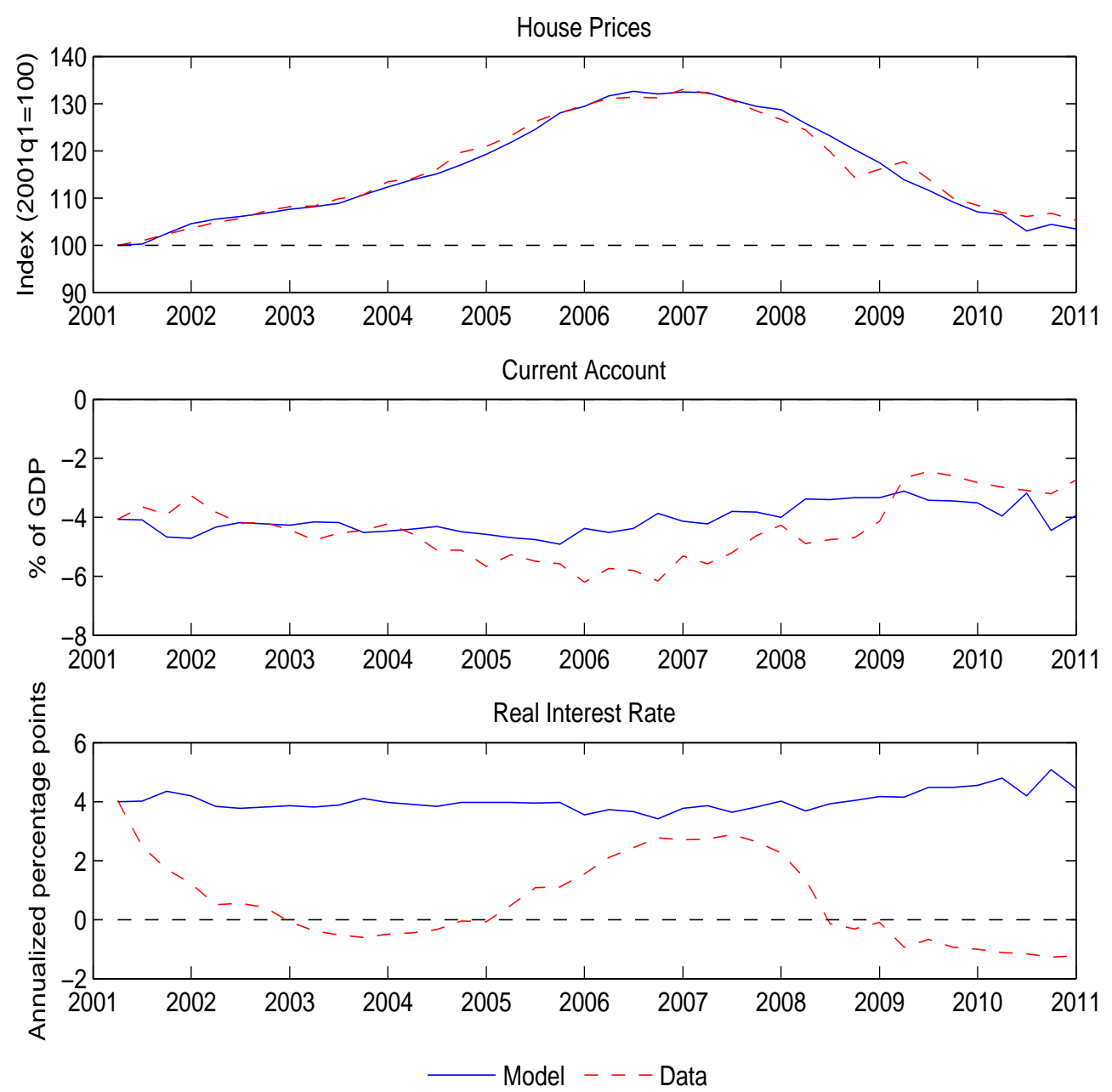

Figure 6: Simulated path of real house prices (top), current account in \% of GDP (center), and real interest rate (bottom), in the baseline scenario (continuous blue line) and in the data (dashed red line).

slightly negative between 2003 and 2005. ${ }^{24}$ Conversely, in the model, real interest rates remain roughly stable, if anything exhibiting a slight increase during the years of the boom and a slight decrease during the early years of the bust. Less stringent lending standards, as well as preference shocks for housing, stimulate aggregate demand in the Home country. As inflation and output tend to rise, the central bank responds hiking the nominal interest rate. During the bust, the adjustment works in reverse. Overall, the magnitude of the real interest rate movements induced by demand shocks is rather small (the standard deviation is 0.08). The model, therefore, misses one important dimension of the global macroeconomic scenario of the

\footnotetext{
${ }^{24}$ Long-term real interest rates behaved similarly during this period. Part of the decline in real interest rates may be due to forces operating at very low frequencies, such as demographic trends (Ferrero, 2010; Favero et al., 2013).
} 
first half of the 2000s.

Part of the recent literature has interpreted the persistent drop in the real interest rate as a consequence of a savings glut originated outside of the U.S. (Bernanke, 2005). ${ }^{25}$ In particular, Caballero et al. (2008b) explicitly link the capital flows associated with the savings glut hypothesis to the housing boom. Even papers that attribute the house price boom to the financial deregulation/innovation process, such as Boz and Mendoza (2014) and Favilukis et al. (2011), have nevertheless relied, at least to some extent, on the savings glut hypothesis. The next section explores a different (and potentially complementary) rationale for low real interests at the world level related to the global prominence of U.S. monetary policy.

\section{The Role of Monetary Policy}

Credit and preference shocks can account for the U.S. boom-bust cycle in house prices and for their negative correlation with the current account, especially during the first half of the 2000s. However, this explanation implies a counterfactual path for the real interest rate. Since the adjustment partly depends on the central bank response to the fundamental drivers of the economy, this section investigates the role of monetary policy as a potential mechanism that keeps world real rates low.

The basic idea is that, if inflation expectations remain well-anchored, a central bank that sets the nominal interest rate essentially controls the real rate. Some observers (most notably Taylor, 2008) have argued that the Federal Reserve, as well as central banks in some other countries, kept nominal interest rates artificially low for too long after the 2001 recession. According to this interpretation, expansionary monetary policy shocks may have contributed to stimulate demand beyond what would be normally considered appropriate according to the predictions of a standard interest rate rule (e.g. Taylor, 1993). Therefore, monetary policy may be responsible not only for low interest rates but also for generating the boom in house prices and contributing to the deterioration of the current account.

While the role of the dollar as a reserve currency may justify the prominent role of U.S. monetary policy in influencing the world real interest rate, overly accommodative U.S. monetary policy alone may not be enough to keep the world real interest rate low for a prolonged period, as nominal exchange rates should adjust to compensate interest rate differentials across countries. However, one notable feature of the late 1990s and early 2000s period is that several emerging market economies - the main counterparties financing the U.S. current account

\footnotetext{
${ }^{25}$ In Caballero et al. (2008a) and Mendoza et al. (2009), financial frictions in emerging economies (either a shortage of collateral or a higher degree of market incompleteness, respectively) lead to capital flows toward the United States. A higher demand for (perceived) safe assets generates a global excess supply of savings and depresses the equilibrium world real interest rate.
} 


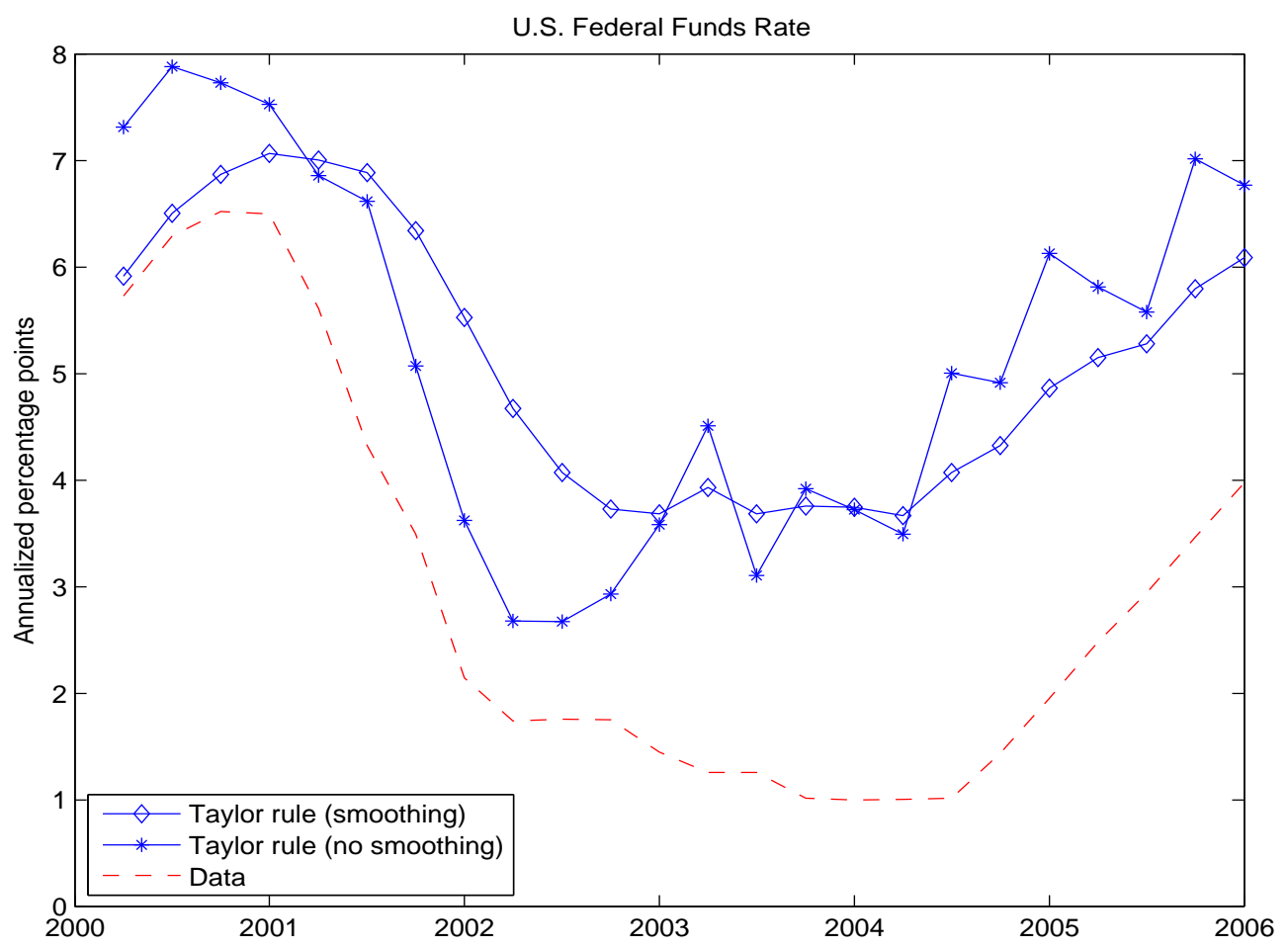

Figure 7: Nominal interest rate predicted by a Taylor rule with (continuous blue line with diamonds) and without (continuous blue line with stars) smoothing, and in the data (dashed red line). Source: Board of Governors of the Federal Reserve, Bureau of Economic Analysis and Bureau of Labor Statistics.

deficit - were pegging their nominal exchange rate to the dollar, thus effectively importing U.S. monetary policy. In this environment, low U.S. interest rates spread globally as pegging countries lose their control on domestic interest rates. ${ }^{26}$ The question then becomes whether foreign exchange rate pegs have exacerbated the magnitude of the adjustment due to U.S. domestic factors.

The next two sections formalize these ideas in the context of the model. The focus is on the boom period (2001-2006), when the path of the actual Federal Funds Rate (FFR) differs most significantly from the predictions of a Taylor rule and several emerging market economies systematically pegged their exchange rate to the dollar.

\subsection{Over-Expansionary U.S. Monetary Policy}

Figure 7 compares the effective FFR in blue with the nominal interest rate predicted by a standard interest rate rule (Taylor, 1993), similar to the linearized version of equation (12) in

\footnotetext{
${ }^{26} \mathrm{~A}$ limit of this argument is that countries can retain some control on domestic monetary policy while pegging their exchange rate by imposing restrictions on foreign capital flows, as in the case of China.
} 
the model

$$
i_{t}=\rho_{i} i_{t-1}+\left(1-\rho_{i}\right)\left(\psi_{\pi} \pi_{t}+\psi_{y} y_{h t}\right)+\varepsilon_{i t},
$$

where $i_{t}$ is the effective FFR, $\pi_{t}$ is the year-over-year CPI inflation rate and $y_{t}$ is the deviation of real GDP from potential output as measured by the Congressional Budget Office. The difference between the two marked blue lines is the value of the smoothing parameter $\rho_{i}$, which is set equal to 0.7 as in the baseline calibration in one case (diamonds) and to zero in the other (stars).

Figure 7 captures the essence of the criticism in Taylor (2008). Between 2001 and 2005, U.S. monetary policy was excessively accommodative compared to the prescriptions of an interest rate rule that characterized well monetary policy in the previous two decades. According to this view, lower interest rates facilitated borrowing and led to higher house prices. Easy monetary policy is then a primary culprit for the house price boom. ${ }^{27}$

Figure 8 compares the path of house prices (top), current account (middle) and real interest rate (bottom) under two experiments. The first (continuous blue line) corresponds to the (baseline) simulation in the previous section. The second experiment (dashed red line) adds to these two shocks a sequence of monetary policy innovations, identified as departures of the effective FFR from the prescriptions of (16). For consistency between model and data, the series of monetary policy shocks is calculated using (16) with $\rho_{i}=0.7$. Interest rate rules that feature a smoothing term generally provide a better fit of the data (Clarida et al., 2000). Furthermore, the presence of the smoothing term introduces some forecastability of previous monetary policy shocks, hence partly capturing the Federal Reserve's communication strategy during the 2003-2004 period.

The top and middle panels of the figure highlight how little monetary policy shocks contribute to house price appreciation and the deterioration of the current account. Borrowing constraint and preference shocks remain pretty much the unique driving force for these two variables. If monetary policy shocks were the only source of variation, house prices and the current account would barely move.

Monetary policy shocks, however, play a key role for the dynamics of the real interest rate (bottom panel of Figure 8). Because the systematic part of the monetary policy rule is unchanged, long-run expected inflation remains anchored, and low nominal rates translate into low real rates, especially at the early stages of the monetary expansion. ${ }^{28}$ As the stimulus

\footnotetext{
${ }^{27}$ The U.S. is not the only country with significant deviations from a standard monetary policy rule (Taylor, 2008). Countries with the largest deviations also experienced the most spectacular booms in housing investment, although the correlation with house price appreciation is much weaker (Bernanke, 2010).

${ }^{28}$ The average increase in one-period-ahead expected inflation over the boom period is half a percentage point
} 

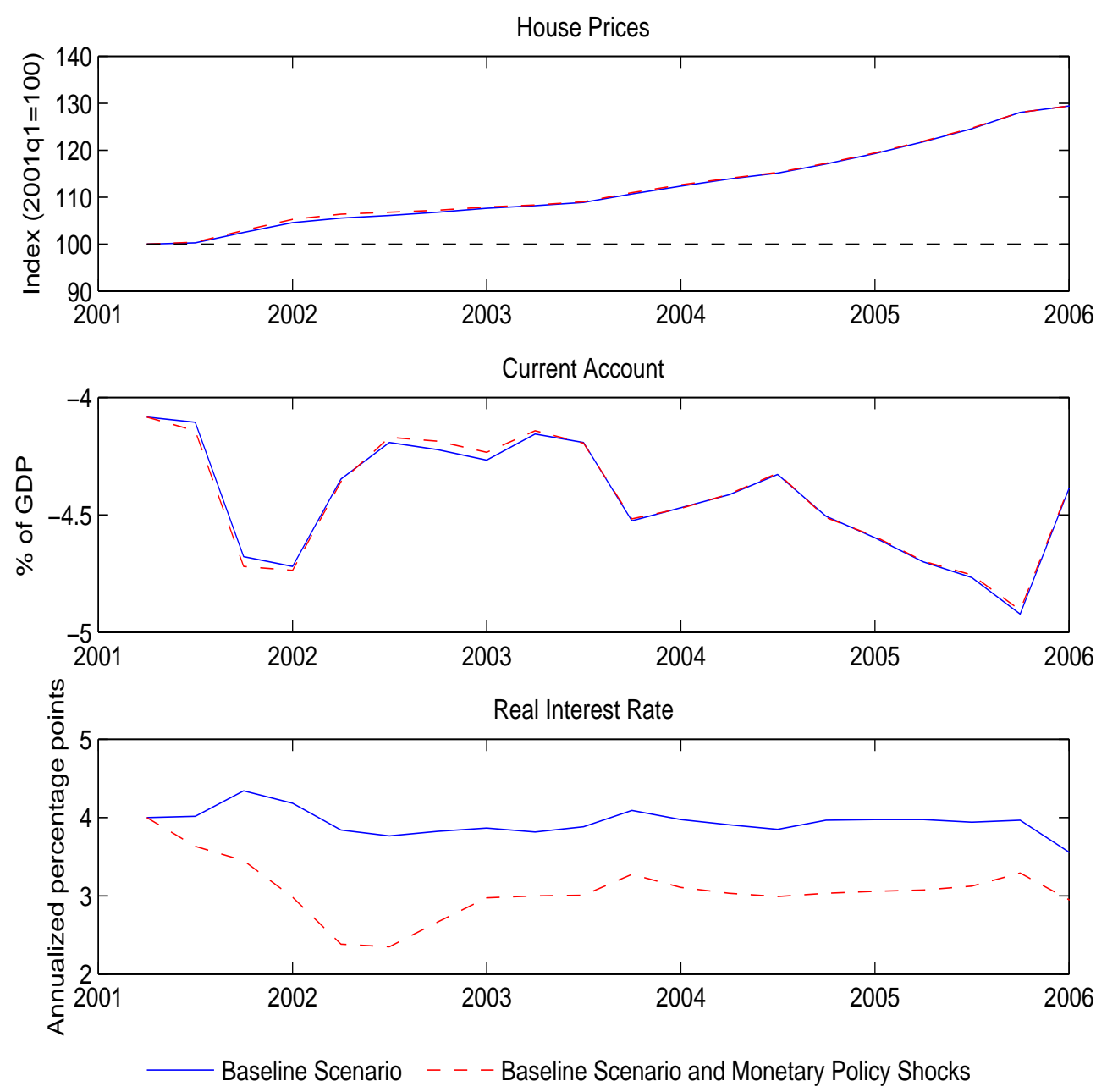

Figure 8: Simulated path of real house prices (top), current account in \% of GDP (center), and real interest rate (bottom), in the baseline scenario (continuous blue line) and in the baseline scenario plus monetary policy shocks (dashed red line).

increases aggregate demand, the central bank responds by tightening the nominal rate, and hence dampening the reduction of the real rate. Overall, the fall in real rates is still less than in the data, but the magnitude is significant - almost $1 \%$ on average over the five-year simulation horizon - and the difference with the case of credit and preference shocks only is quite notable.

Low real rates also contribute to stimulate consumption. Absent monetary policy shocks, the endogenous initial increase in nominal rates counteracts the stimulus associated with the collateral channel. Conversely, the monetary expansion generates an average demand boom close to $3 \%$, comparable to the $2 \%$ average deviation of non-durable consumption relative to trend over the period 2001-2006.

annualized. 


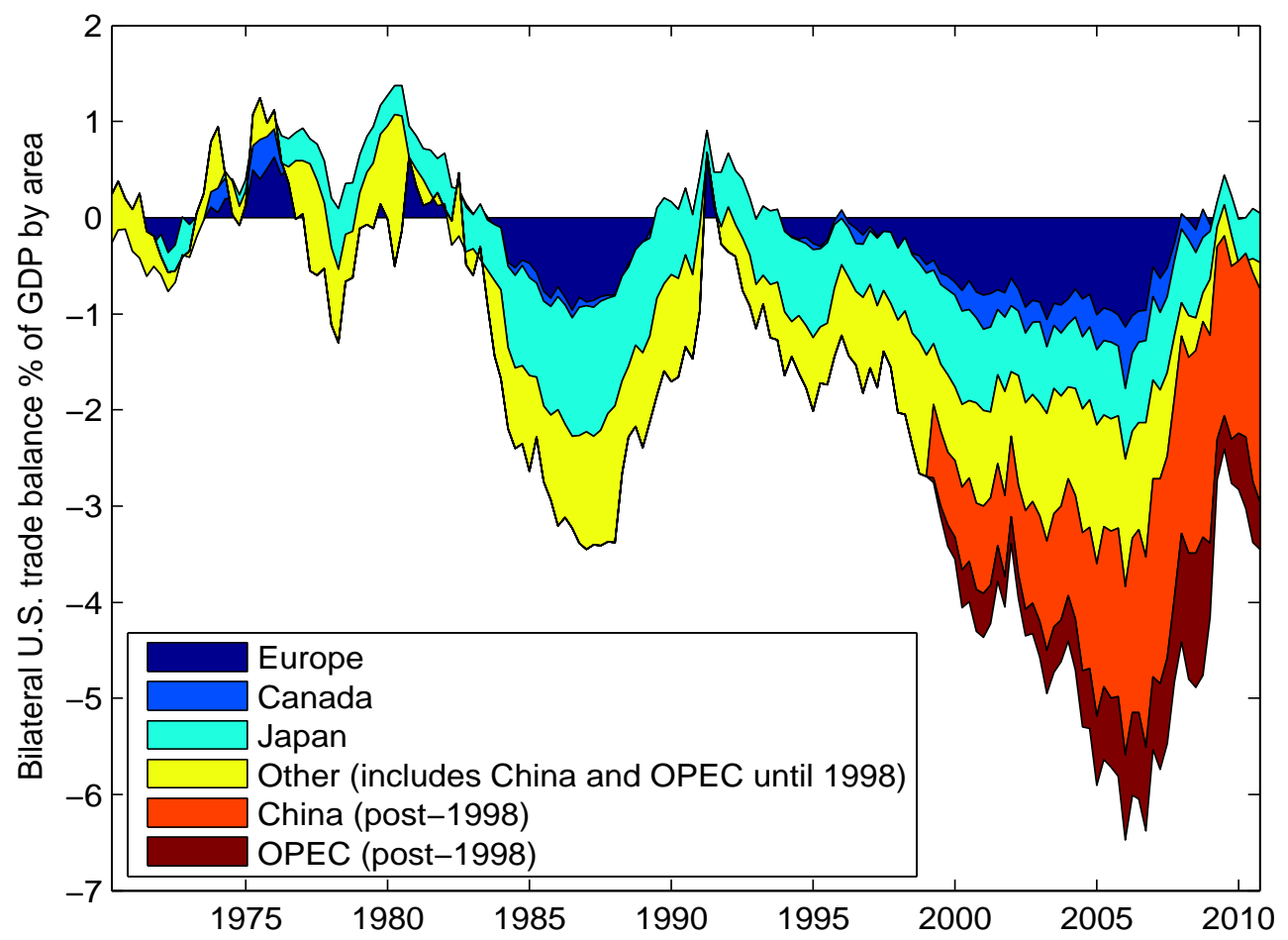

Figure 9: Bilateral U.S. trade balance \% of GDP by area. Source: Bureau of Economic Analysis and author's calculations.

The introduction of monetary policy shocks improves the empirical performance of the model in terms of the real interest rate and real activity, leaving unchanged the fit of house price dynamics and the negative correlation with the current account balance. The fall in the real interest rate, however, is still less pronounced than in the data. The next section explores the role of the exchange rate regime in the rest of the world in accounting for the missing portion.

\subsection{Foreign Exchange Rate Pegs}

One important feature of the international monetary system since the late 1990s is the fact that many emerging economies, primarily in East Asia (and most notably China) and among oil producers, have pegged their exchange rate to the U.S. dollar. ${ }^{29}$

Dooley et al. (2008) have called this extensive peg arrangement "Bretton Woods II." In their view, pegged exchange rates among fast-growing, export-oriented economies are responsible for the large external imbalances between the U.S. and the rest of the world. Indeed, these

\footnotetext{
${ }^{29}$ See the International Monetary Fund exchange rate regime classification, summarized for the period 1970-2007 in Reinhart and Rogoff (2009).
} 

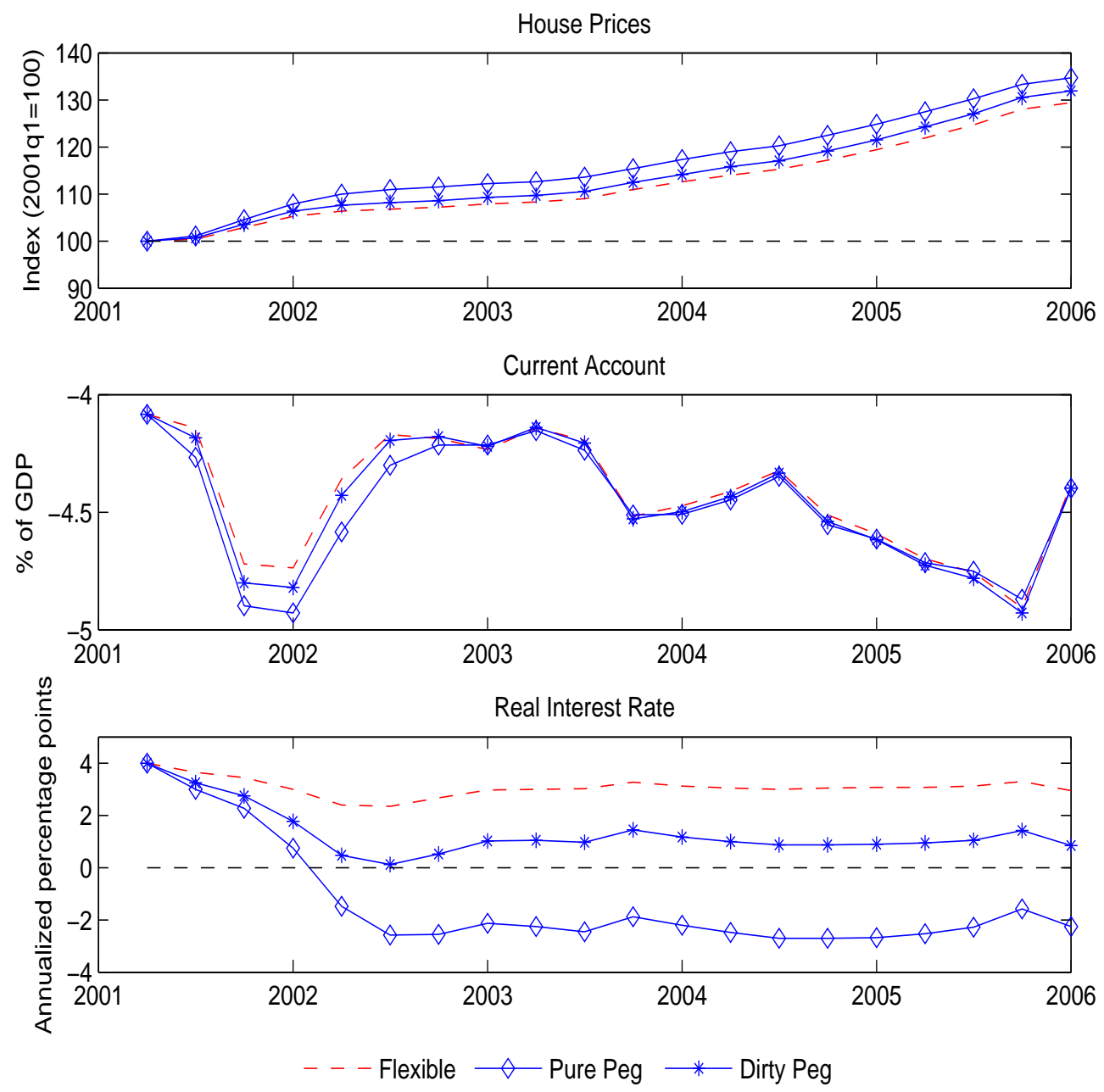

Figure 10: Simulated path of real house prices (top), current account in \% of GDP (center), and real interest rate (bottom) in the baseline scenario plus monetary policy shocks under a flexible exchange rate regime (dashed red line), a pure Foreign peg (continuous blue line with diamonds), and a dirty Foreign peg (continuous blue line with stars).

countries have played a major role in financing the U.S. external imbalances in recent years (Figure 9).

The intuition is that pegged exchange rates keep foreign currencies significantly below their true market value, hence stimulating exports and growth abroad. From the perspective of the emerging economies, the peg may have been a reasonable policy. The consequence for the U.S., however, has been a series of widening current account deficits. For the purpose of this paper, the key question is how much foreign exchange rate pegs have contributed to exacerbate the boom in house prices.

Figure 10 compares the simulation in the previous section (dashed red line) with two cases in which the monetary authority of country $\mathrm{F}$ responds to the nominal exchange rate. In the 
first case (continuous blue line with diamonds), the Foreign central bank follows a pure peg

$$
\Delta e_{t}=0
$$

In the second case, the Foreign country Taylor rule places a positive weight on the depreciation of the nominal exchange rate

$$
i_{t}^{*}=\rho_{i} i_{t-1}^{*}+\left(1-\rho_{i}\right)\left(\psi_{\pi} \pi_{t}^{*}+\psi_{y} y_{f t}\right)-\psi_{e} \Delta e_{t}+\varepsilon_{i t}^{*},
$$

with $\psi_{e}>0$.

Qualitatively, the consequences of the two exchange rate regimes for the international macroeconomic adjustment are the same. The Foreign response to the exchange rate does not significantly change the dynamics of house prices and the current account. Inspecting the Fisher parity condition $\left(r_{t}=i_{t}-\mathbb{E}_{t} \pi_{t+1}\right)$ suggests that both the fall in the nominal interest rate and the increase in expected inflation are larger under a peg than in the case of flexible exchange rates, although the first component tends to dominate. In a floating environment, as monetary policy becomes more expansionary, not only domestic demand rises, but also the nominal exchange rate tends to depreciate, making Home goods more attractive for foreigners. Higher foreign demand stimulates domestic production and leads to an increase in domestic prices. As a consequence, the endogenous component of the interest rate rule partly compensates for the exogenous expansionary shocks. This mechanism is absent under a peg. In this case, the increase in prices occurs mostly abroad. The Home country exports the main consequences of its expansionary monetary policy (see Ferrero et al., 2010, for a similar result). Lower nominal interest rates at Home, however, do imply higher short-run expected domestic inflation (in spite of the absence of a nominal depreciation), which further reduces the real interest rate.

Quantitatively, house prices are on average 4 percentage points higher (5.5 percentage point differential at the peak) under a pure peg. Fixed exchange rates magnify the current account deficit during the first year of the simulation, but the effect is relatively small (less than a quarter of a percentage point at the peak). The main difference concerns the real interest rate, which drops more than five times as much than in the flexible exchange rate regime. Obviously, a pure peg in the rest of the world is an extreme characterization of the true international system of exchange rates. Indeed, in this case, the real interest rate falls significantly more than in the data and the domestic nominal interest rate violates the zero lower bound.

A more realistic approach is to assume that the Foreign country follows a dirty peg. The coefficient on the exchange rate depreciation in the Foreign Taylor rule $\left(\psi_{e}=1\right)$ is calibrated so that the U.S. nominal interest rate remains positive throughout the sample. In this case, the adjustment of house prices and the current account essentially coincides with the flexible 
exchange rate scenario, while the real interest rate drops close to zero between 2002 and 2003 and stays below $1 \%$ until 2006, thus providing a good fit of the data without the extreme consequences of a pure peg.

All in all, assuming the Foreign country pegs its nominal exchange rate to the Home currency (whether fully or partially) helps the model align better with the data in terms of the behavior of the real interest rate, without substantially affecting the dynamics of house prices and the current account.

\section{Conclusions}

Domestic factors, such as credit and preference shocks, can explain the full increase in U.S. house prices between 2001 and 2006, and, at the same, give rise to substantial current account deficits. Contrary to the evidence, however, domestic shocks cannot account for the fall of the real interest rate. These two empirical observations - negative correlation between house prices and current account and low real rates - can be reconciled by considering expansionary monetary policy shocks, measured as departures of the nominal interest rate from the predictions of a conventional interest rate rule. An exchange rate regime based on foreign pegs to the dollar exports U.S. monetary policy to the rest of the world, thus amplifying the effect of domestic expansionary shocks.

Except for the role of the foreign exchange rate regime, this explanation of house prices booms and current account deficits has its origins in U.S. behavior and policies. This approach contrasts with recent contributions based on the idea of a foreign savings glut. The two hypotheses are not mutually exclusive. Abstracting from the details about its ultimate source, a foreign savings glut would generate additional financial flows from the rest of world, thus amplifying the consequences of domestic shocks, worsening the Home country current account deficit, and further depressing the world real interest rate. All in all, the mechanism at play in this paper would result strengthened.

The results clearly suggest a dichotomy in accounting for house prices and the current account on the one hand, and the real interest rate on the other. In the model, the exogenous driving forces are orthogonal to each other. In practice, low interest rates may have encouraged excessive risk-taking by both individuals and financial institutions, fueling the housing bubble and planting the seeds of the crisis. Simple regressions of LTV ratios on policy rates (available in the Appendix) do not support any role for monetary policy in explaining the actual deterioration of credit standards. Nevertheless, the risk-taking channel of monetary policy may operate along different dimensions, not yet fully understood. More broadly, investigating the optimal joint design of monetary a macro-prudential policies in an environment with financial 
frictions, in particular in relation to the housing market, should represent a high priority in the research agenda going forward. 


\section{References}

Abraham, J., A. Pavlov, and S. Wachter (2008). Explaining the United States' Uniquely Bad Housing Market. Wharton Real Estate Review XII (Fall).

Acharya, V. and P. Schnabl (2010). Do Global Banks Spread Global Imbalances? The Case of Asset-Backed Commercial Paper during the Financial Crisis of 2007-09. IMF Economic Review 58, 37-73.

Bernanke, B. (2005). The Global Saving Glut and the U.S. Current Account Deficit. Remarks at The Homer Jones Lecture. St. Louis, MO.

Bernanke, B. (2010). Monetary Policy and the Housing Bubble. Speech at the Annual Meeting of the American Economic Association. Atlanta, GA.

Boz, E. and E. Mendoza (2014). Financial Innovation, the Discovery of Risk, and the U.S. Credit Crisis. Journal of Monetary Economics 62, 1-22.

Brown, M., A. Haugwout, D. Lee, and W. V. der Klaauw (2013). The Financial Crisis at the Kitchen Table: Trends in Household Debt and Credit. Current Issues in Economics and Finance 19(2).

Bruno, V. and H. Shin (2014). Cross-Border Banking and Global Liquidity. Unpublished, Princeton University.

Caballero, R., E. Farhi, and P.-O. Gourinchas (2008a). An Equilibrium Model of 'Global Imbalances' and Low Interest Rates. American Economic Review 98, 358-393.

Caballero, R., E. Farhi, and P.-O. Gourinchas (2008b). Financial Crash, Commodity Prices and Global Imbalances. Brookings Papers on Economic Activity, 1-55.

Campbell, J. and Z. Hercowitz (2005). The Role of Collateralized Household Debt in Macroeconomic Stabilization. Working Papers 11330, NBER.

Clarida, R., J. Gali, and M. Gertler (2000). Monetary Policy Rules And Macroeconomic Stability: Evidence And Some Theory. Quarterly Journal of Economics 115, 147-180.

Cortina, A. (2009). The Residential Boom and Its Consequences: A View from a Spanish Bank. Presentation at the SUERF/Bank of Finland Conference: "Housing Markets: A Shelter From the Storm or a Cause of the Storm?". 
Davis, M. and J. Heathcote (2007). The Price and Quantity of Residential Land in the United States. Journal of Monetary Economics 54, 2595-2620.

Davis, M. and F. Ortalo-Magné (2011). Household Expenditures, Wages, Rents. Review of Economic Dynamics 14, 248-261.

Diaz, A. and M. J. Luengo-Prado (2008). On the User Cost and Homeownership. Review of Economic Dynamics 11, 584-613.

Dooley, M., D. Folkerts-Landau, and P. Garber (2008). Asia, Interest Rates, and the Dollar. Global Markets Research March, Deutsche Bank.

Duca, J., J. Muellbauer, and A. Murphy (2010). Housing Markets and the Financial Crisis of 2007-2009: Lessons for the Future. Journal of Financial Stability 6, 203-217.

Duca, J., J. Muellbauer, and A. Murphy (2011). Shifting Credit Standards and the Boom and Bust in U.S. House Prices. Discussion Paper 76, SERC.

Duca, J., J. Muellbauer, and A. Murphy (2012). How Financial Innovations and Accelerators Drive Booms and Busts in U.S. Consumption. Unpublished, Federal Reserve Bank of Dallas.

Dynan, K., D. Elmendorf, and D. Sichel (2006). Can Financial Innovation Help to Explain the Reduced Volatility of Economic Activity? Journal of Monetary Economics 53, 123-150.

Eggertsson, G. and P. Krugman (2012). Debt, Deleveraging, and the Liquidity Trap: A Fisher-Minsky-Koo Approach. Quarterly Journal of Economics 127, 1469-1513.

European Mortgage Federation (2008). Hypostat: A Review of Europe's Mortgage and Housing Markets.

Favara, G. and J. Imbs (2010). Credit Supply and the Price of Housing. Discussion Paper 8129, CEPR.

Favero, C., A. Gozluklu, and H. Yang (2013). Demographics and the Behavior of Interest Rates. Unpublished, Bocconi University.

Favilukis, J., S. Ludvigson, D. Kohn, and S. Van Nieuwerburgh (2013). International Capital Flows and House Prices: Theory and Evidence. In E. Glaeser and T. Sinai (Eds.), Housing and the Financial Crisis, Chapter 6, pp. 235-299. University of Chicago Press.

Favilukis, J., S. Ludvigson, and S. Van Nieuwerburgh (2011). The Macroeconomic Effects of Housing Wealth, Housing Finance, and Limited Risk-Sharing in General Equilibrium. Unpublished, London School of Economics. 
Ferrero, A. (2010). A Structural Decomposition of the U.S. Trade Balance: Productivity, Demographics and Fiscal Policy. Journal of Monetary Economics 57, 478-490.

Ferrero, A., M. Gertler, and L. E. Svensson (2010). Current Account Dynamics and Monetary Policy. In J. Galí and M. Gertler (Eds.), International Dimensions of Monetary Policy, Chapter 4, pp. 199-244. University of Chicago Press.

Galí, J. and M. Gertler (2007). Macroeconomic Modeling for Monetary Policy Evaluation. Journal of Economic Perspectives 21, 25-46.

Geanakoplos, J. (2010a). Solving the Present Crisis and Managing the Leverage Cycle. FRBNY Economic Policy Review 16, 101-131.

Geanakoplos, J. (2010b). The Leverage Cycle. In D. Acemoglu, K. Rogoff, and M. Woodford (Eds.), NBER Macroeconomics Annual 2009, Chapter 1, pp. 1-65. University of Chicago Press.

Gete, P. (2013). Housing Demand and Current Account Dynamics. Unpublished, Georgetown University.

Glaeser, E., J. Gottlieb, and J. Gyourko (2013). Can Cheap Credit Explain the Housing Boom? In E. Glaeser and T. Sinai (Eds.), Housing and the Financial Crisis, Chapter 7, pp. 301-359. University of Chicago Press.

Greenspan, A. (2005). Closing Remarks. In The Greenspan Era: Lessons for the Future, pp. 549-551. Federal Reserve Bank of Kansas City Symposium, Jackson Hole, WY.

Greenspan, A. and J. Kennedy (2008). Sources and Uses of Equity Extracted from Homes. Oxford Review of Economic Policy 24, 120-144.

Guerrieri, V. and G. Lorenzoni (2012). Credit Crises, Precautionary Savings and the Liquidity Trap. Unpublished, University of Chicago Booth School of Business.

Hall, R. (2010). Why Does the Economy Fall to Pieces after a Financial Crisis? Journal of Economic Perspectives 24, 3-20.

Haughwout, A., D. Lee, J. Tracy, and W. Van der Klaauw (2011). Real Estate Investors, the Leverage Cycle, and the Housing Market Crisis. Staff Reports 514, Federal Reserve Bank of New York.

Iacoviello, M. (2005). House Prices, Borrowing Constraints, and Monetary Policy in the Business Cycle. American Economic Review 95, 739-764. 
Iacoviello, M. and S. Neri (2010). Housing Market Spillovers: Evidence from an Estimated DSGE Model. American Economic Journal: Macroeconomics 2, 125-164.

Justiniano, A., G. Primiceri, and A. Tambalotti (2013). Household Leveraging and Deleveraging. Working Paper 18941, NBER.

Justiniano, A., G. Primiceri, and A. Tambalotti (2014a). Credit Supply and the Housing Boom. Unpublished, Federal Reserve Bank of Chicago.

Justiniano, A., G. Primiceri, and A. Tambalotti (2014b). The Effect of the Saving and Banking Glut on the U.S. Economy. Journal of International Economics 92, S52-S67.

Kiyotaki, N. and J. Moore (1997). Credit Cycles. Journal of Political Economy 105, 211-248.

Kocherlakota, N. R. (2000). Creating Business Cycles Through Credit Constraints. Federal Reserve Bank of Minnesota Quarterly Review 24, 2-10.

Kuvshinov, D. (2010). Recent Trends in the UK First-Time Buyer Mortgage Market. Unpublished, Bank of England.

McCarthy, J. and R. Peach (2010). The Measurement of Rent Inflation. Staff Report 425, Federal Reserve Bank of New York.

McCarthy, Y. and K. McQuinn (2013). Credit Conditions in a Boom and Bust Property Market. Research Technical Paper 8/RT/13, Central Bank of Ireland.

Mendoza, E., V. Quadrini, and J.-V. Rios-Rull (2009). Financial Integration, Financial Development, and Global Imbalances. Journal of Political Economy 117, 371-416.

Mian, A. and A. Sufi (2011). House Prices, Home Equity-Based Borrowing, and the U.S. Household Leverage Crisis. American Economic Review 101, 2132-2156.

Mian, A., A. Sufi, and F. Trebbi (2013). The Political Economy of the Subprime Mortgage Credit Expansion. Unpublished, Chicago Booth.

Midrigan, V. and T. Philippon (2011). Household Leverage and the Recession. Working Paper 16965, NBER.

Nakamura, E. and J. Steinsson (2008). Five Facts About Prices: A Reevaluation of Menu Cost Models. Quarterly Journal of Economics 123(4), 1415-1464. 
Obstfeld, M. and K. Rogoff (2007). The Unsustainable U.S. Current Account Deficit Revisited. In R. Clarida (Ed.), G7 Current Account Imbalances: Sustainability and Adjustment, Chapter 9, pp. 339-376. University of Chicago Press.

Obstfeld, M. and K. Rogoff (2010). Global Imbalances and the Financial Crisis: Products of Common Causes. In Asia and the Global Financial Crisis, pp. 131-172. Federal Reserve Bank of San Francisco's Center for Pacific Basin Studies Asia Economic Policy Conference.

Ortalo-Magné, F. and S. Rady (2004). Housing Transactions and Macroeconomic Fluctuations: A Case Study of England and Wales. Journal of Housing Economics 13, 287-303.

Piazzesi, M., M. Schneider, and S. Tuzel (2007). Housing, Consumption and Asset Pricing. Journal of Financial Economics 83, 531-569.

Punzi, M. T. (2013). Housing Market and Current Account Imbalances in the International Economy. Review of International Economics 21, 601-613.

Rajan, R. (2010). Fault Lines. How Hidden Fractures Still Threaten the World Economy. Princeton University Press.

Reinhart, C. and K. Rogoff (2009). This Time Is Different: Eight Centuries of Financial Folly. Princeton University Press.

Sá, F. and T. Wieladek (2011). Monetary Policy, Capital Inflows and the Housing Bubble. Globalization and Monetary Policy Institute Working Paper 80, Federal Reserve Bank of Dallas.

Schmitt-Grohé, S. and M. Uribe (2003). Closing Small Open Economy Models. Journal of International Economics 61, 163-185.

Shiller, R. (2007). Understanding Recent Trends in House Prices and Homeownership. In Housing, Housing Finance, and Monetary Policy, pp. 89-123. Federal Reserve Bank of Kansas City Symposium, Jackson Hole, WY.

Taylor, J. (1993). Discretion versus Policy Rules in Practice. Carnegie-Rochester Conference Series on Public Policy 39, 195-214.

Taylor, J. B. (2008). The Financial Crisis and the Policy Responses: An Empirical Analysis of What Went Wrong. In A Festschrift in Honour of David Dodge, Chapter 1, pp. 1-18. Bank of Canada. 
Williams, D. (2009). House Prices and Financial Liberalisation in Australia. Unpublished, University of Oxford.

Woodford, M. (2003). Interest and Prices: Foundations of a Theory of Monetary Policy. Princeton University Press. 